\title{
A Tale of Two Diversifications: Reciprocal Habitat Shifts to Fill Ecological Space along the Pond Permanence Gradient
}

\author{
Robby Stoks ${ }^{1,2}$ and Mark A. McPeek ${ }^{1, *}$ \\ 1. Department of Biological Sciences, Dartmouth College, \\ Hanover, New Hampshire 03755; \\ 2. Laboratory of Aquatic Ecology, Catholic University of Leuven, \\ Charles de Beriotstraat 32, B-3000 Leuven, Belgium
}

\begin{abstract}
Aвstract: The Enallagma and Lestes damselflies have both diversified and adapted over the past 10-15 million years to the various ecological milieus found along the pond permanence gradient among North American ponds and lakes. Previous articles have explored this diversification process for Enallagma. In this article, we present a phylogenetic hypothesis for the North American Lestes, use this hypothesis to reconstruct Lestes diversification, and compare the diversification processes inferred for Lestes and Enallagma. The results of this study suggest that Lestes began in temporary ponds where large dragonflies are the top predators, while Enallagma began in permanent lakes where fish are the top predators. Starting from these different ancestral habitats, both genera have invaded and adapted to habitats already occupied by the other genus. Moreover, these adaptive habitat shifts involved substantial convergence on the behaviors used to deal with fish and dragonfly predation in both genera and a major life-history shift from diapausing to directly developing eggs in Lestes. However, in Lestes lineages invading fish lakes, swimming speed and morphology did not change to match those of Enallagma species, illustrating that reciprocal shifts between alternative selection regimes are not necessarily evolutionary opposites. Also, the greater sizes and growth rates of Lestes species compared to Enallagma species, which should impart substantial ecological advantages in competition between the genera, were shown to result from phylogenetic inheritance and not from adaptive diversification. This historical analysis of diversification raises new questions about the relationship between the macroevolutionary mechanisms driving lineage diversification and the ecological mechanisms structuring local food webs and regional species assemblages.
\end{abstract}

Keywords: adaptation, antipredator behavior, community structure, ecomorphology, Enallagma, Lestes, Odonata, speciation.

Questioning how biological communities are assembled has been a long-standing endeavor for community ecology

\footnotetext{
* Corresponding author; e-mail: mark.mcpeek@dartmouth.edu.
}

Am. Nat. 2006. Vol. 168, pp. S50-S72. (c) 2006 by The University of Chicago. 0003-0147/2006/1680S6-41368\$15.00. All rights reserved. (e.g., MacArthur 1972; Diamond 1975). Most theoretical explorations of this problem begin by constructing a pool of species with the ability to interact with one another that is drawn from some specified random distributions. Species are then chosen from this pool and allowed to colonize some community or metacommunity, and patterns in the properties of co-occurring species are evaluated once a stable configuration is reached (e.g., Gilpin 1975; Tregonning and Roberts 1978; Pimm 1982; Loreau and Mouquet 1999; Mouquet and Loureau 2002, 2003; Mouquet et al. 2003; Fukami 2004; Tilman 2004). We have learned a tremendous amount from these studies, but the metaphor of drawing colonizing species from a random species pool is directly applicable for only a limited number of systems: for example, communities on islands where species colonize mainly from a mainland source pool, or communities where invasive species predominate. This metaphor may lead us astray when species have long evolutionary histories with one another. In such systems, community properties will be strongly influenced by the diversification and adaptation of component taxa in response to abiotic gradients and interactions with one another within that biogeographic region. Comparisons of systems in abiotically similar but biogeographically separate areas sometimes find similar community structures (e.g., Losos 1992; Losos et al. 1998) and sometimes find different structures (e.g., Schluter 1986). Commonalities are typically attributed to parallel evolution in response to similar selection pressures (e.g., Harmon et al. 2005), and dissimilarities are typically attributed to the unique properties of the taxa and the adaptations that are possible to them, given their initial phenotypes and genetic constitutions (e.g., Price et al. 2000).

Understanding features of the diversification and adaptation of component lineages also provides strong insights into the development of overall food web structure in a system. The generation of new functional groups via ecological speciation or their loss via extinction can profoundly alter food web structure. For example, Enallagma damselflies are an important functional group in the littoral food webs of fishless lakes in eastern North America (McPeek 1998), but this functional group seems to have 
arisen only within the past 110,000 years (Turgeon et al. 2005). Before this functional group was present, food web dynamics in fishless lakes presumably were quite different (Holt et al. 1994; Leibold 1996; McPeek 1996). Such differences resulting from different adaptive evolutionary dynamics are also apparent across the landscape within some systems today (e.g., one-stickleback-species versus twostickleback-species lakes on Vancouver Island [Schluter and McPhail 1993], missing ecomorphs of anoles on some Caribbean islands [Losos et al. 1998], alternative coevolutionary dynamics [Thompson 1999, 2005]). In addition, nonadaptive evolutionary diversification may also profoundly influence community metrics, such as species richness, without altering overall food web structure. For example, in many animal taxa, many new species have been introduced into systems by speciation via sexual selection, with little or no ecological differentiation (e.g., Kaneshiro and Boake 1987; Seehausen et al. 1997; Henry et al. 1999; Mendelson and Shaw 2005). Food web dynamics should regulate and respond to the total abundance of all these ecologically similar species in the functional group, but species abundances within the functional group may follow neutral dynamics (Hubbell 2001; McPeek and Gomulkiewicz 2005; Leibold and McPeek 2006). Thus, in systems where species have long evolutionary histories, the development of community structure cannot be divorced from the processes shaping the diversification of component taxa, because they are one and the same.

Exploring the evolutionary development of community structure in any particular system requires integrating information about many different features of interacting taxa. The first necessity is a phylogenetic history of the taxa to provide a diversification framework on which community development can be reconstructed. The best history would be derived from a complete or nearly complete fossil record, but such records would be available for only a few groups (e.g., corals [Jackson and Cheetham 1994], mammals [Kurtén and Anderson 1980]). For taxa lacking an adequate fossil record, molecular systematics provides an alternative (Webb et al. 2002). Obviously, phylogenies derived from molecular data have a number of shortcomings relative to a good fossil record. First, extinct species are invisible to molecular phylogenetic analyses. In addition, such analyses only generate hypotheses about the true phylogenetic relationships among taxa, and subsequent inferences are predicated on the assumption of these hypotheses being true. Finally, inferences about the temporal sequence of events are also predicated on the approximate clocklike nature of molecular substitutions. Thus, inferences must be made cautiously in this context.

Reconstructing community development also mandates a thorough understanding of the ecological agents that limit the distributions and abundances of component taxa and the phenotypes that influence their performances in interactions with these ecological agents. In an evolutionary context, ecological agents limiting distributions and abundances must also have been significant agents of natural selection for community members, if adaptation played an important role in shaping community structure. Changes in ecologically important phenotypes then identify adaptive responses of component taxa to these selective agents. Reconstructing the evolutionary history of phenotypic traits that determine ecological performance thus provides evolutionary and historical context for how the communities we study today came to be.

In this article, we compare the adaptation and diversification of two genera of damselflies (Odonata: Zygoptera) into the littoral food webs of ponds and lakes across North America. Previous field experiments have identified the major agents that limit the distributions of Enallagma and Lestes species along the gradient of pond permanence from small, temporary ponds that dry each year to large lakes that support fish populations (Pierce et al. 1985; McPeek 1990b, 1998; Stoks and McPeek 2003b). Functional studies have also identified ecologically important phenotypes that limit the distributions of species along this gradient and that influence population regulation (Pierce et al. 1985; McPeek 1990a, 1995a, 1999, 2004; McPeek et al. 1996; Stoks and McPeek 2003a; Stoks et al. 2003). Previous analyses have explored the diversification of Enallagma throughout the Holarctic (e.g., McPeek and Brown 2000; Stoks et al. 2005b). Here, we focus on Lestes diversification and the comparison of the two genera in eastern North America, where most of our ecological work has been done. First, we develop a phylogenetic hypothesis for many of the North American Lestes based on mitochondrial DNA sequences. We then compare the phenotypes of Enallagma and Lestes species found in different lake types without applying any phylogenetic corrections, in order to compare the phenotypes in their ecologically relevant contexts. Finally, we combine the phylogenetic hypothesis with the phenotypic analysis by applying evolutionary contrasts analyses to critical Lestes phenotypes to identify phenotypic differences that arose via adaptive divergence of lineages. We use these results to infer the historical development of damselfly assemblage structure in eastern North American ponds and lakes over the past 10-15 million years.

\section{Background}

Enallagma and Lestes are the two most abundant damselfly genera, in terms of both overall biomass and species richness, inhabiting the littoral zones of ponds and lakes in eastern North America (Johnson and Crowley 1980; McPeek 1990b, 1998; Stoks and McPeek 2003b). Larvae 
in both genera cling to plants growing in the littoral zone, and multiple species of both genera can be captured with one short sweep of a net through the plants growing in a lake (Johnson and Crowley 1980; McPeek 1990b, 1998; Stoks and McPeek 2003b). In addition, many species in both genera have ranges that stretch over latitudes from the Gulf of Mexico to Canada and over longitudes from the Atlantic to the Pacific Ocean (Donnelly 2004). Thus, individuals in these two genera routinely interact across North America.

In each genus, species segregate along the pond permanence gradient (Wellborn et al. 1996), but the two genera show very different distributional patterns along the gradient (e.g., fig. 1). The segregation of species identifies four main ecological regions along this gradient that are characterized by whether water is present year-round and by the top predators that dominate each. These are (1) small, temporary ponds that dry each year and as a result are essentially predator free from a damselfly's perspective; (2) temporary ponds that may dry once every few to tens of years and that have large dragonflies as top predators; (3) permanent ponds and lakes that retain water for many, many years (possibly drying only in the most severe of climatic conditions) and also have large dragonflies as top predators; and (4) permanent ponds and lakes that have fish as the top predators (Johnson and Crowley 1980; McPeek 1990b, 1998; Werner and McPeek 1994; Wellborn et al. 1996; Stoks and McPeek 2003a; fig. 1; a different set of smaller, less voracious dragonflies coexists with fish [Johnson and Crowley 1980; McPeek 1998]).

All Enallagma and Lestes species in North America are univoltine, but life-history differences between species cause the segregation of species between temporary and permanent waters. All Enallagma lay eggs that directly hatch into aquatic larvae in the late summer, overwinter as larvae, metamorphose into terrestrial adults the following spring, and lay eggs to begin a new generation. This life cycle, with its long aquatic larval phase, restricts Enallagma species to ponds and lakes that hold water yearround (fig. 1). In contrast to Enallagma, most Lestes species inhabit temporary ponds in which water may be completely absent for part of the year (fig. 1). Like Enallagma, all Lestes species oviposit in the summer, but the eggs of these temporary-pond species enter diapause and remain dormant until the following spring, when ponds thaw. Then eggs break diapause, hatch, rapidly develop as aquatic larvae, and metamorphose into adults to lay eggs, all in 2-3 months (Gower and Kormondy 1963; Sawchyn and Gillott 1974a, 1974b; Jödicke 1997). Most of these species are found in ponds and lakes that do not dry in every year (Wiggins et al. 1980; Stoks and McPeek 2003b). Only three Lestes species have directly hatching eggs, and like Enallagma, these species overwinter as aquatic larvae

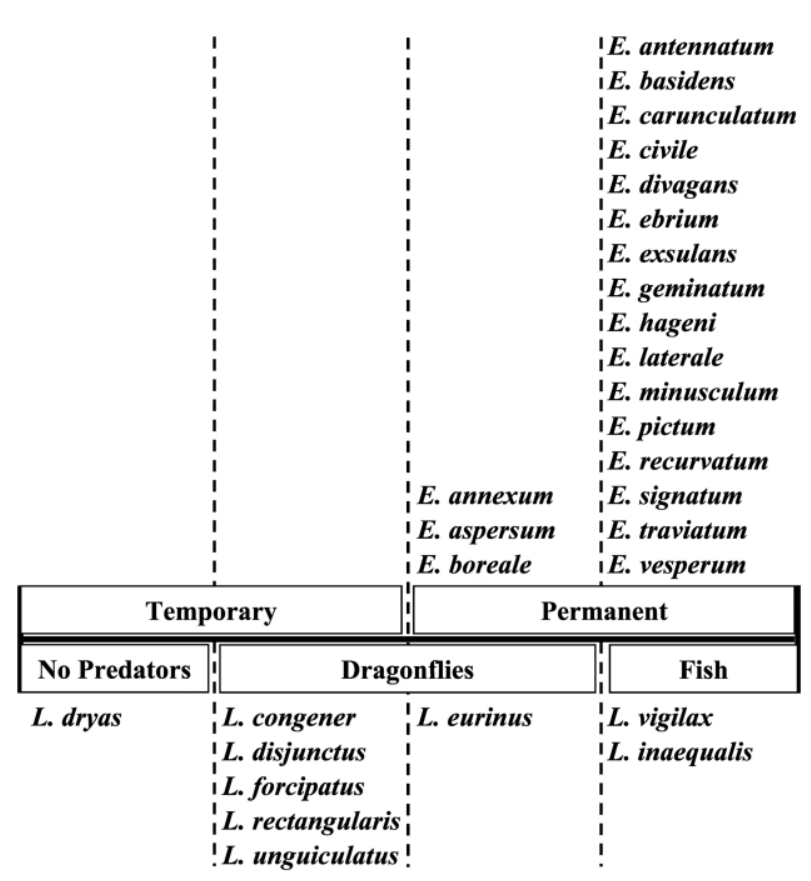

Figure 1: Checklist of Enallagma and Lestes species found at the four types of pond and lake habitats in New England. For any given lake type, multiple species can be found co-occurring in any particular lake. Although many of the specific species identities change, the same patterns of distribution are apparent across eastern North America.

and are thus restricted to permanent waters (fig. 1; Lutz 1968a, 1968b; Lutz and Pittman 1968; Paulson and Jenner 1971; Johnson and Crowley 1980; McPeek 1990b; Stoks and McPeek 2003b).

In addition, susceptibilities to different predators cause further species segregation along the gradient (McPeek 1990b; Stoks and McPeek 2003b). In eastern North America, four Enallagma species are found as larvae only in permanent dragonfly ponds (Johnson and Crowley 1980; McPeek 1990b, 1998; fig. 1). However, most Enallagma species are found as larvae only in permanent water bodies with insectivorous fish (Johnson and Crowley 1980; McPeek 1990b, 1998; fig. 1). Likewise, the three Lestes species that are restricted to permanent waters also segregate as larvae between fish and dragonfly waters (fig. 1; Stoks and McPeek 2003b). In addition, intraguild predation by Lestes eurinus excludes the temporarydragonfly-pond species from permanent dragonfly ponds (Stoks and McPeek 2003b). Finally, one species-Lestes dryas - inhabits small, temporary ponds that are essentially predator free as far as Lestes are concerned.

Consistent phenotypic differences among species in the various lake type categories make them differentially vulnerable to fish and dragonfly predators. Fish-lake species 
in both genera move and feed less in the absence of predators than species that coexist with large dragonflies, and they respond to the presence of both fish and dragonflies by decreasing their activity (Pierce et al. 1985; McPeek 1990b; Stoks and McPeek 2003a; Stoks et al. 2003). Also, when attacked by a predator, they most frequently do not try to flee until the predator has made physical contact with them (Pierce et al. 1985; McPeek 1990a; Stoks and McPeek 2003b). Activity attracts the attention of predators (Elkin and Baker 2000; Stoks and Johansson 2000; Stoks et al. 2005c), and because escape from the much faster fish after being detected is nearly impossible, the fish-lake species' whole demeanors appear to be tailored to minimize detection by fish.

In contrast, species in both genera that live with large dragonflies in fishless ponds are more active in the absence of predators and decrease their activity only in the presence of dragonflies (Pierce et al. 1985; McPeek 1990b; Stoks and McPeek 2003a; Stoks et al. 2003). (Larvae of multiple Enallagma species, when raised from eggs in the absence of predators, decreased activity when placed in the presence of their natural predators for the first time, indicating that these species differences are innate and not learned responses; F. Strobbe, R. Stoks, and M. A. McPeek, unpublished data.) Moreover, these species flee attacking predators by swimming, which is an effective strategy against dragonflies but a deadly one against fish (Pierce et al. 1985; McPeek 1990a; Stoks and McPeek 2003a). Finally, L. dryas, which lives in an essentially predator-free habitat, is more active than any other Lestes and does not respond to the presence of fish or dragonflies (Stoks and McPeek 2003a).

Larval growth rates should also influence fitness in important ways. Faster larval growth rates overall will decrease the time that species are exposed to larval predators in general and also should increase the likelihood that larvae emerge from temporary ponds. The presence of predators depresses the growth rates of both Enallagma and Lestes species with which they coexist (McPeek et al. 2001; Stoks and McPeek 2003a; McPeek 2004). Thus, differential responses by the genera may have important consequences for inhabiting different portions of the habitat gradient.

\section{Material and Methods}

\section{Phylogenetic Analyses of Lestes}

Lestes adult males were collected at ponds across North America for the phylogenetic analysis. We obtained specimens for 10 of the 17 North American species listed by Westfall and May (1996) for this study (table 1). Species not included were three Caribbean species (Lestes scalaris, Lestes spumarius, and Lestes tenuatus), one southeastern coastal plain endemic species (Lestes vidua), and three southwestern and Mexican species (Lestes alacer, Lestes forficula, and Lestes sigma). We included Archilestes grandis, a member of the only other North American Lestidae genus (Westfall and May 1996) as the outgroup for our analyses. Sample sizes and sampling localities are given in table 1.

Total DNA was extracted from specimens using either a standard phenol-chloroform extraction or a diatomaceous earth extraction method using guanidine thiocyanate (protocol of T. Glenn, Savannah River Ecology Laboratory; http://www.uga.edu/srel/DNA_Lab/protocols $. \mathrm{htm})$. Three separate mitochondrial DNA (mtDNA) fragments were amplified from two to six individuals of each species. We included individuals from multiple populations when possible. One mtDNA fragment was a 550-bp fragment that we amplified using the primers developed by Weller et al. (1994). Alignment of this fragment with Drosophila melanogaster mtDNA (accession M37275) indicated that it included an 84-bp untranscribed spacer region, a leucine transfer RNA (tRNA) of $67 \mathrm{bp}$, a second 11-bp untranscribed spacer, and finally a 388-bp $5^{\prime}$ fragment of the ND1 subunit gene. We therefore identify this fragment as ND1. The second was a 567-bp fragment of the large ribosomal subunit (16S) that we amplified using the primers $5^{\prime}$-CGC CTG TTT ATC AAA AAC AT- ${ }^{\prime}$ (Simon et al. 1994) and 5'-CCG GTT GAA CTC AGA TCA-3' (Kambhampati and Smith 1995). Alignment of this fragment with another D. melanogaster mtDNA isolate (accession AF200829) indicated that the 16S fragment was completely internal to the $16 \mathrm{~S}$ gene. The third was a 978 bp fragment spanning the cytochrome oxidase I and II genes and the intervening leucine tRNA (CO) that we amplified using the primers described in Turgeon and McPeek (2002). We amplified these fragments in separate PCR reactions, using standard protocols described in the above references. The PCR products were purified by band extraction from a $1 \%$ agarose gel using the Qiagen gel extraction kit. Cycle sequencing was performed using the ABI BigDye, version 3.1, chemistry, run according to manufacturer's recommended protocol, and scored on an ABI 3100 automated DNA sequencer. Representative sequences were deposited in GenBank upon acceptance of this article for publication (accession nos. EF44250-EF44274).

Phylogenetic analyses were performed using PAUP*, version 4.0b10 (Swofford 2001). Preliminary analyses of each mtDNA fragment separately using all amplified individuals showed that all species formed monophyletic groups, except for the two pairs Lestes disjunctus-Lestes rectangularis and Lestes dryas-Lestes stultus (analyses not shown). We attributed the lack of monophyly within these two species pairs as resulting from their very recent divergence (see Turgeon et al. 2005 for other very recent 
Table 1: Lestes species included in this study

\begin{tabular}{|c|c|c|c|c|}
\hline Species & $\begin{array}{l}\text { Dominant } \\
\text { predator }\end{array}$ & $\begin{array}{l}\text { Winter } \\
\text { stage }\end{array}$ & $\begin{array}{c}\text { Sample site } \\
\text { (no. of specimens) }\end{array}$ & References \\
\hline Archilestes grandis & Dragonflies & Egg & $\begin{array}{l}\text { Garden Canyon, Cochise } \\
\text { County, AZ (2) }\end{array}$ & $\begin{array}{l}\text { Ingram 1976; Johnson and Crowley 1980; Wiseman et } \\
\text { al. } 1993\end{array}$ \\
\hline L. congener & Dragonflies & Egg & $\begin{array}{l}\text { Logging Pond, Norwich, VT (2); } \\
\text { Montana (1) }\end{array}$ & $\begin{array}{l}\text { Sawchyn and Gillott 1974b; Stoks and McPeek 2003b; } \\
\text { M. A. McPeek and R. Stoks, personal observations }\end{array}$ \\
\hline \multicolumn{5}{|l|}{ L. disjunctus: } \\
\hline L. disjunctus disjunctus & Dragonflies & Egg & $\begin{array}{l}\text { Appalachian Trail Pond, Etna, } \\
\text { NH (1); Logging Pond, Nor- } \\
\text { wich, VT (1) }\end{array}$ & $\begin{array}{l}\text { Sawchyn and Gillott } 1974 a \text {; Baker and Clifford 1981; } \\
\text { Duffy 1994; Stoks and McPeek 2003b; M. A. Mc- } \\
\text { Peek and R. Stoks, personal observations }\end{array}$ \\
\hline L. disjunctus australis & Dragonflies & Egg & $\begin{array}{l}\text { Flood control ponds, Harris } \\
\text { County, TX (2) }\end{array}$ & $\begin{array}{l}\text { Sawchyn and Gillott 1974a; Baker and Clifford 1981; } \\
\text { Duffy 1994; Stoks and McPeek 2003b; M. A. Mc- } \\
\text { Peek and R. Stoks, personal observations }\end{array}$ \\
\hline L. dryas & None & Egg & $\begin{array}{l}\text { Fairy Shrimp Pond, Norwich, } \\
\text { VT (2) }\end{array}$ & $\begin{array}{l}\text { Gardner 1952; Sawchyn and Gillott } 1974 a \text {; Stoks and } \\
\text { McPeek 2003b; M. A. McPeek and R. Stoks, per- } \\
\text { sonal observations }\end{array}$ \\
\hline L. eurinus & Dragonflies & Larva & Sylvester Pond, Norwich, VT (2) & $\begin{array}{l}\text { Lutz 1968a, 1968b; Paulson and Jenner 1971; Johnson } \\
\text { and Crowley 1980; Wiseman et al. 1993; Stoks and } \\
\text { McPeek 2003b }\end{array}$ \\
\hline L. forcipatus & Dragonflies & Egg & $\begin{array}{l}\text { Logging Pond, Norwich, VT (1); } \\
\text { Moose Mountain Pond, Etna, } \\
\text { NH (3) }\end{array}$ & $\begin{array}{l}\text { Stoks and McPeek 2003b; M. A. McPeek and R. Stoks, } \\
\text { personal observations }\end{array}$ \\
\hline L. inaequalis & Fish & Larva & $\begin{array}{l}\text { Reed's Marsh, Orford, NH (1); } \\
\text { Duck Lake, Pinckney, MI (1) }\end{array}$ & M. A. McPeek and R. Stoks, personal observations \\
\hline L. rectangularis & Dragonflies & Egg & $\begin{array}{l}\text { Moose Mountain Pond, Etna, } \\
\text { NH (2); Deep Marsh, Has- } \\
\text { tings, MI (2); George's Re- } \\
\text { serve, Pinckney, MI (1) }\end{array}$ & $\begin{array}{l}\text { Gower and Kormondy 1963; Stoks and McPeek } \\
\text { 2003b; M. A. McPeek and R. Stoks, personal } \\
\text { observations }\end{array}$ \\
\hline L. stultus & $?$ & $?$ & $\begin{array}{l}\text { Table Top Mountain, Oroville, } \\
\text { CA (2) }\end{array}$ & \\
\hline L. unguiculatus & Dragonflies & Egg & $\begin{array}{l}\text { Deep Marsh, Hastings, MI (1); } \\
\text { George's Reserve, Pinckney, } \\
\text { MI (1) }\end{array}$ & $\begin{array}{l}\text { Sawchyn and Gillott } 1974 a \text {; M. A. McPeek and R. } \\
\text { Stoks, personal observations }\end{array}$ \\
\hline L. vigilax & Fish & Larva & $\begin{array}{l}\text { Baker River, Gilman's Corner, } \\
\text { NH (2); Palmatier Lake, Has- } \\
\text { tings, MI (1); Otis Lake, Has- } \\
\text { tings, MI (1); Child's Pond, } \\
\text { Thetford, VT (1) }\end{array}$ & $\begin{array}{l}\text { Paulson and Jenner 1971; Johnson and Crowley 1980; } \\
\text { Stoks and McPeek 2003b; M. A. McPeek and R. } \\
\text { Stoks, personal observations }\end{array}$ \\
\hline
\end{tabular}

Note: The dominant predator type found in ponds where the species lives, the stage that overwinters in ponds, sites and sizes for samples included in the Lestes phylogenetic analysis, and references for this life-history feature are included.

radiations of damselfly lineages). To speed analyses, we randomly selected one individual per species to include in the full analysis, concatenated the three mtDNA fragments into one large data set, and analyzed this concatenated data set. Our results were not different among different sets of randomly chosen individuals or when all individuals were included in analyses of individual mtDNA fragments. Despite intensive effort that included designing alternative primers, we were unable to amplify the $\mathrm{CO}$ fragment from Lestes congener. As a result, we have performed two sets of analyses: (1) all species, using only the $16 \mathrm{~S}$ and ND1 data, and (2) all species except $L$. congener, using data from all three mtDNA fragments.

First, we conducted a maximum parsimony analysis using the branch-and-bound algorithm to find the most parsimonious trees and calculated bootstrapped support val- ues $(1,000$ replicates) for the various nodes in these trees, using the heuristic search algorithm with the tree bisection reconnection and steepest-descent options. Gaps were coded as a fifth base in the maximum parsimony analyses. We also conducted maximum likelihood and minimum evolution analyses. Modeltest, version 3.06 (Posada and Crandall 1998), was used in conjunction with PAUP* to first determine the most likely model of nucleotide substitution for the concatenated data set. We then assumed that model in analyses using maximum likelihood and distance criteria to find the shortest trees, using heuristic searches. We also calculated bootstrap support (1,000 replicates) for each analysis. Because all analyses gave identical results for branching patterns and qualitative levels of bootstrap support for nodes, we present results for only the maximum likelihood analyses. 


\section{Phenotypic Patterns}

We compared ecologically important phenotypes of Lestes and Enallagma species from along the pond permanence gradient. We have previously reported analyses for many of these phenotypes separately for each genus. These include the behavior of larvae in the presence and absence of dragonfly and fish predators (McPeek 1990b; Stoks and McPeek 2003a, 2003b; Stoks et al. 2003), the growth and digestive physiological capabilities of species in the presence and absence of their native predators (McPeek et al. 2001; Stoks and McPeek 2003a; McPeek 2004) for both genera, and the swimming capabilities and associated morphological features for Enallagma (McPeek 1995a, 1999, 2000; McPeek et al. 1996). A summary of species included in each study, sample sizes, citations for data previously published, and the identification of new data in these analyses are given in table 2. Because the methods used to gather these results have been described in detail in previous publications, we present only brief summaries of the methods for each study here.

Behavior. The behaviors of final-instar larvae of $11 \mathrm{En}$ allagma and seven Lestes species were observed under three predator presence treatments to quantify their behavioral repertoires under these varying conditions (table 2). The Enallagma data include three permanent-dragonfly-lake species (E. annexum, E. aspersum, and E. boreale) and eight fish-lake species (E. divagans, E. ebrium, E. exsulans, E. geminatum, E. hageni, E. signatum, E. vernale, and E. vesperum). The Lestes data include one predator-freetemporary-pond species (L. dryas), four species from temporary dragonfly ponds (L. congener, L. disjunctus, L. forcipatus, and L. rectangularis), one species from permanent dragonfly ponds (L. eurinus), and one fish-lake species ( $L$. vigilax; table 2 ). Solitary larvae were observed in (1) the absence of predators, (2) the presence of final-instar Anax junius dragonflies, or (3) the presence of a Lepomis sp. sunfish (Lepomis macrochirus or Lepomis gibbosus for Enallagma and L. gibbosus for Lestes). Three to 12 larvae per species were included in each treatment $(75 \%$ of species had eight or more replicate larvae per treatment). For each trial, a larva was placed in a $10.0 \times 10.5-\mathrm{cm}$ Plexiglas inner compartment surrounded by a $34.5 \times 24.0-\mathrm{cm}$ outer container in which the predator treatments were constructed. Daphnia pulex were added to this inner compartment as prey for the damselfly (30 for Enallagma, 60 for Lestes). All behaviors of the larva were then recorded for a set period (30 min for Enallagma, $20 \mathrm{~min}$ for Lestes).

Previous analyses of both genera showed that the number of moves performed in trials and the single longest period of complete inactivity are highly correlated with derived principal component axes of the overall data sets that are interpreted as overall measures of "activity." Also, the number of prey eaten in a trial correlated with all other behavioral variables associated with responsiveness to prey. Because these variables should strongly correlate with features that attract the attention of visual predators (Baker et al. 1999; Elkin and Baker 2000; Stoks and Johansson 2000; Stoks et al. 2005c) and are highly correlated with summary measures of activity and responsiveness to prey, we focus on these variables in comparing Enallagma and Lestes behaviors. Because trials were of different durations for the genera, we present the number of moves and prey eaten as a rate (e.g., number of moves per minute). Also, because Lestes are substantially larger and can eat more prey than Enallagma, we also standardize the number of prey captured by the average wet mass of final instars for that species.

Our purpose here is to compare the phenotypes of species found in different lake types and in different genera. We interpret the values of the three variables in each predator treatment as a different set of phenotypes: thus, the number of moves in the three predator treatments defines three phenotypes for a species. Previous analyses have evaluated whether species responded differently to the predator treatments. For analyses presented here, we first calculate the means of each variable in each treatment for each species. These means are then used as data in ANOVAs (Sokal and Rohlf 1995) comparing the genera and differences between species found in the different lake types. (Throughout the article, figures present within-treatment standard errors to provide the reader with some idea of the variation within a predator treatment for each species, but this within-treatment variability does not factor into the analyses.)

Morphology. The ecomorphologies of final-instar larvae of 13 Enallagma and eight Lestes species were quantified (table 2). The Enallagma data include four permanentdragonfly-lake species (E. annexum, E. aspersum, E. boreale, and E. doubledayi) and eight fish-lake species (E. antennatum, E. davisi, E. exsulans, E. geminatum, E. hageni, E. signatum, E. traviatum, and E. vesperum). The Lestes data include one predator-free-temporary-pond species ( $L$. dryas), four species from temporary dragonfly ponds $(L$. congener, L. disjunctus, L. forcipatus, and L. rectangularis), one species from permanent dragonfly ponds (L. eurinus), and two fish-lake species (L. inaequalis and L. vigilax).

We measured distances between landmarks to quantify the morphologies of abdomens, legs, and caudal lamellae of these 21 species. All measurements were made as reported in McPeek (1995a). Briefly, final-instar larvae with unregenerated legs and caudal lamellae were collected in the field and preserved in $70 \%$ ethanol until digitized. Abdomens, back and middle legs, and median and lateral 
Table 2: Sample sizes for the four phenotypic studies presented in this article

\begin{tabular}{lccccc}
\hline Species & Habitat $^{\mathrm{a}}$ & Behavior $^{\mathrm{M}}$ & Morphology & Swimming & Physiology \\
\hline Enallagma annexum & $\mathrm{PD}$ & $24^{\mathrm{b}}$ & 28 & $38^{\mathrm{c}}$ & $18^{\mathrm{d}}$ \\
Enallagma aspersum & $\mathrm{PD}$ & $24^{\mathrm{b}, \mathrm{e}}$ & $16^{\mathrm{f}}$ & $38^{\mathrm{c}}$ & $33^{\mathrm{d}}$ \\
Enallagma boreale & $\mathrm{PD}$ & $24^{\mathrm{b}}$ & 55 & $45^{\mathrm{c}}$ & $\ldots$ \\
Enallagma doubledayi & $\mathrm{PD}$ & $\ldots$ & 8 & $\ldots$ & $\ldots$ \\
Enallagma antennatum & $\mathrm{PF}$ & $\ldots$ & $12^{\mathrm{f}}$ & $\ldots$ & $\ldots$ \\
Enallagma daeckii & $\mathrm{PF}$ & $\ldots$ & $\ldots$ & $10^{\mathrm{c}}$ & $\ldots$ \\
Enallagma davisi & $\mathrm{PF}$ & $\ldots$ & 1 & $\ldots$ & $\ldots$ \\
Enallagma divagans & $\mathrm{PF}$ & $24^{\mathrm{b}}$ & $\ldots$ & $37^{\mathrm{c}}$ & $75^{\mathrm{d}}$ \\
Enallagma ebrium & $\mathrm{PF}$ & $24^{\mathrm{b}}$ & $\ldots$ & $29^{\mathrm{c}}$ & $40^{\mathrm{d}}$ \\
Enallagma exsulans & $\mathrm{PF}$ & 15 & 14 & $22^{\mathrm{c}}$ & $\ldots$ \\
Enallagma geminatum & $\mathrm{PF}$ & $15^{\mathrm{b}, \mathrm{e}}$ & $48^{\mathrm{f}}$ & $49^{\mathrm{c}}$ & $20^{\mathrm{d}}$ \\
Enallagma hageni & $\mathrm{PF}$ & $24^{\mathrm{b}}$ & $22^{\mathrm{f}}$ & $20^{\mathrm{c}}$ & $28^{\mathrm{d}}$ \\
Enallagma laterale & $\mathrm{PF}$ & $\ldots$ & $\ldots$ & $34^{\mathrm{c}}$ & $24^{\mathrm{g}}$ \\
Enallagma pictum & $\mathrm{PF}$ & $\ldots$ & $\ldots$ & $12^{\mathrm{c}}$ & $\ldots$ \\
Enallagma recurvatum & $\mathrm{PF}$ & $\ldots$ & $\ldots$ & $8^{\mathrm{c}}$ & $\ldots$ \\
Enallagma signatum & $\mathrm{PF}$ & $24^{\mathrm{b}}$ & $24^{\mathrm{f}}$ & $6^{\mathrm{c}}$ & $50^{\mathrm{d}}$ \\
Enallagma traviatum & $\mathrm{PF}$ & $\ldots$ & $24^{\mathrm{f}}$ & $\ldots$ & $\ldots$ \\
Enallagma vernale & $\mathrm{PF}$ & $24^{\mathrm{b}}$ & $\ldots$ & $\ldots$ & $\ldots$ \\
Enallagma vesperum & $\mathrm{PF}$ & $24^{\mathrm{b}, \mathrm{e}}$ & $22^{\mathrm{f}}$ & $15^{\mathrm{c}}$ & $43^{\mathrm{d}}$ \\
Lestes dryas & $\mathrm{VN}$ & $24^{\mathrm{h}}$ & 24 & 36 & $20^{\mathrm{h}}$ \\
Lestes congener & $\mathrm{TD}$ & $24^{\mathrm{h}}$ & 23 & 51 & 32 \\
Lestes disjunctus & $\mathrm{TD}$ & $9^{\mathrm{h}}$ & 10 & 7 & 13 \\
Lestes forcipatus & $\mathrm{TD}$ & $18^{\mathrm{h}}$ & 24 & 36 & 18 \\
Lestes rectangularis & $\mathrm{TD}$ & $24^{\mathrm{h}}$ & 24 & 52 & $20^{\mathrm{h}}$ \\
Lestes eurinus & $\mathrm{PD}$ & $24^{\mathrm{h}}$ & 24 & 44 & $20^{\mathrm{h}}$ \\
Lestes inaequalis & $\mathrm{PF}$ & $\ldots$ & 4 & $\ldots$ & $\ldots$ \\
Lestes vigilax & $\mathrm{PF}$ & $24^{\mathrm{h}}$ & 24 & 47 & $20^{\mathrm{h}}$ \\
\hline
\end{tabular}

Note: Each cell in the table gives the number of larvae included in the study. Sample sizes without accompanying citations are new data.

a Pond type and top predator: $\mathrm{PD}=$ permanent, dragonflies; $\mathrm{PF}=$ permanent, fish; $\mathrm{VN}=$ vernal (temporary), no predators; TD $=$ temporary, dragonflies.

b Stoks et al. 2003.

c McPeek 1999.

${ }^{d}$ McPeek 2004.

e McPeek 1990a.

${ }^{\mathrm{f}}$ McPeek 1995a.

${ }^{\mathrm{g}}$ McPeek et al. 2001.

${ }^{\mathrm{h}}$ Stoks and McPeek 2003a.

lamellae were digitized by magnifying the larva with a dissecting microscope and digitizing distances and areas using Image-Pro Plus software, version 5.1 (Media Cybernetics, San Diego, CA). The landmarks and the set of distances between them that were included in analyses are given in figure 1 of McPeek (1995a). The landmark set for legs measured the lengths and widths of the six segments of the larval leg (a total of 18 distances for each leg). The landmark set for the abdomen quantified the widths and lengths of the last six abdominal segments when viewing the ventral surface (seven widths and 12 lengths [two per segment]). For lamellae, we digitized the outline of the each lamella, and from that we calculated the lateral area, the perimeter distance, the length of the major axis, and the maximum breadth. We also digitized three landmark points on the perimeter (the two points at the ends of the suture line where the lamella attaches to the body and the lamella tip) and calculated the distances among these three landmarks and the distances from each of these landmarks to the centroid of the lamella.

We first reduced the dimensionality of these data by performing principal component (PC) analyses separately for each of the three structures, including all individuals in the analyses without regard to genus or species. For each structure, we extracted the first two PCs from the covariance matrix among the distances and areas measured on the structure and calculated PC scores for each individual. The PCs were interpreted by the magnitude and sign of factor loadings (table 3 ). We then calculated the 
mean of each PC for each species and used these as data in ANOVAs (Sokal and Rohlf 1995) comparing the genera and differences between species found in the different lake types.

Swimming. We measured the fastest swimming speed for larvae of 14 Enallagma and seven Lestes species over a large size range for each species (table 2). The Enallagma data include three permanent-dragonfly-lake species (E. annexum, E. aspersum, and E. boreale) and 11 fish-lake species (E. daeckii, E. divagans, E. ebrium, E. exsulans, E. geminatum, E. hageni, E. laterale, E. pictum, E. recurvatum, E. signatum, and E. vesperum). The Lestes data include one predator-free-temporary-pond species (L. dryas), four species from temporary dragonfly ponds (L. congener, L. disjunctus, L. forcipatus, and L. rectangularis), one species from permanent dragonfly ponds (L. eurinus), and one fish-lake species ( $L$. vigilax). All methods and measurements were made as reported in McPeek (1999).

Briefly, for each species, six to 52 wild-caught larvae over a wide size range were induced to swim in a bare Plexiglas container by gently tapping their abdomens with a thin metal spatula. We videotaped each larva performing up to six swims (we could not induce some larvae to swim; McPeek 1999, 2000), and we digitized the two or three fastest swims of each larva. Analyses presented here are based on the fastest swim performed by each larva. Immediately after the swimming trial, each larva was weighed to determine its wet mass $(\mathrm{mg})$. We use wet mass as a measure of larval size.

A full, self-contained analysis of swimming speed would entail an ANCOVA that included data for all larvae measured for all species and terms identifying each larva's genus, lake type, the covariate of wet mass, species identity nested within genus, and all the interaction terms among these various main effects. This analysis in its complete form is so cumbersome as to be almost uninterpretable. Moreover, the imbalance of species numbers among lake types for the two genera makes the construction of acceptable error terms impossible. Therefore, we have taken a two-step approach that accomplishes the same goals. First, we included all species in both genera in a simple ANCOVA, including only species, wet mass, and their interaction in the model. We calculated least squares means (Sokal and Rohlf 1995) in this analysis to generate a standardized measure of swimming speed across all species. We then used these least squares means as the data in ANOVAs to test hypotheses about differences among genera and species living with different predators. This approach is conceptually comparable to the full analysis, since the appropriate error terms in the full analyses involve variance among species within each group.

As in almost any ANCOVA involving this many species, slopes were significantly heterogeneous among species $(F=9.56, \mathrm{df}=20,613, P<.0001)$. Least squares means calculated from the model assuming heterogeneity of slopes were highly correlated with those derived from the model assuming homogeneous slopes $(r=0.83, N=$ $20, P<.0001$ ), and all subsequent analyses gave similar results for these two sets of least squares means. We therefore present results only for the least squares means derived from the model allowing heterogeneous slopes.

Digestive Physiology. We also compared the behavioral and physiological underpinnings of growth rate for larvae of 12 Enallagma and seven Lestes species over a large size range for each species (table 2). The Enallagma data include three permanent-dragonfly-lake species (E. annexum, E. aspersum, and E. boreale) and nine fish-lake species (E. divagans, E. ebrium, E. exsulans, E. geminatum, E. hageni, E. laterale, E. signatum, E. vernale, and E. vesperum). The Lestes data include one predator-freetemporary-pond species (L. dryas), four species from temporary dragonfly ponds ( $L$. congener, $L$. disjunctus, $L$. forcipatus, and $L$. rectangularis), one species from permanent dragonfly ponds (L. eurinus), and one fish-lake species (L. vigilax).

Briefly, within species, larvae were placed in one of two treatments: (1) held in complete isolation from all mortality threats or (2) placed in the presence of their native predator and other individuals of their genus. Five to 28 larvae were included in each treatment for each species. Larvae held in complete isolation were placed in a $20-\mathrm{mL}$ glass vial with pond water and a wooden dowel, and the vial was placed in a tray with cardboard dividers so that each larva could see no other damselfly or predator. Larvae held in the presence of their native predator were placed in an identical vial with wooden dowel, but the vial was floated in a 38-L aquarium filled with pond water and containing other vials with damselflies and either a Lepomis gibbosus sunfish or final-instar A. junius dragonfly larvae, depending on the species. Each larva was then fed measured, ad lib. amounts of $D$. pulex for 4 days. The wet mass of each larva was measured at the beginning and end of the feeding period to calculate the rate of mass gain. Each day, we also collected uneaten food from the previous day and fecal pellets; these were dried and weighed so we could calculate a series of digestive parameters. Those parameters were (1) the amount of food ingested, (2) assimilation efficiency (i.e., the amount of food assimilated/amount of food ingested), (3) production efficiency (i.e., [final dry mass - initial mass]/amount of food assimilated), and (4) growth rate (i.e., $\log _{\mathrm{e}}$ [(final wet mass) $-\log _{\mathrm{e}}$ (initial wet mass)]/4 days). Based on previous wet mass-to-dry mass regressions, we assumed that dry mass $=0.15 \times$ wet mass (McPeek 2004). Previous anal- 
Table 3: Loadings for the first two principal components extracted from the landmark data for the legs, abdomens, and caudal lamellae of Enallagma and Lestes species

\begin{tabular}{|c|c|c|c|c|c|}
\hline Landmarks & PC1 & PC2 & Landmarks & $\mathrm{PC} 1$ & PC2 \\
\hline Legs: & & & Abdomen: & & \\
\hline$\%$ of variation & 97.9 & .8 & $\%$ of variation & 84.0 & 9.1 \\
\hline MLEG1 & .012 & .018 & $\mathrm{ABD} 1$ & .036 & .134 \\
\hline MLEG2 & .325 & .375 & $\mathrm{ABD} 2$ & .114 & .072 \\
\hline MLEG3 & .328 & .344 & ABD3 & .107 & .081 \\
\hline MLEG4 & .009 & .033 & $\mathrm{ABD} 4$ & .103 & .203 \\
\hline MLEG5 & .009 & .016 & ABD5 & .261 & .052 \\
\hline MLEG6 & .321 & .378 & ABD6 & .259 & .042 \\
\hline MLEG7 & .322 & .359 & ABD7 & .152 & .269 \\
\hline MLEG8 & .004 & .008 & ABD8 & .269 & -.069 \\
\hline MLEG9 & .004 & -.005 & ABD9 & .273 & -.054 \\
\hline MLEG10 & .013 & -.019 & $\mathrm{ABD} 10$ & .159 & .328 \\
\hline MLEG11 & .017 & .048 & ABD11 & .275 & -.160 \\
\hline MLEG12 & .006 & .025 & $\mathrm{ABD} 12$ & .275 & -.168 \\
\hline MLEG13 & .045 & .091 & ABD13 & .173 & .385 \\
\hline MLEG14 & .046 & .047 & $\mathrm{ABD} 14$ & .295 & -.210 \\
\hline MLEG15 & .006 & -.001 & ABD15 & .298 & -.221 \\
\hline MLEG16 & .060 & .064 & ABD16 & .179 & .421 \\
\hline MLEG17 & .065 & .070 & ABD17 & .324 & -.186 \\
\hline MLEG18 & .002 & -.004 & ABD18 & .326 & -.198 \\
\hline BLEG1 & .015 & -.008 & ABD19 & .171 & .433 \\
\hline BLEG2 & .362 & -.276 & Caudal lamellae: & & \\
\hline BLEG3 & .362 & -.353 & $\%$ of variation & 95.3 & 3.1 \\
\hline BLEG4 & .012 & -.008 & LATLAM1 & .018 & -.015 \\
\hline BLEG5 & .009 & .005 & LATLAM2 & .185 & .213 \\
\hline BLEG6 & .378 & -.318 & LATLAM3 & .186 & .210 \\
\hline BLEG7 & .380 & -.366 & LATLAM4 & .081 & .126 \\
\hline BLEG8 & .006 & -.002 & LATLAM5 & .082 & .124 \\
\hline BLEG9 & .005 & -.010 & LATLAM6 & .104 & .086 \\
\hline BLEG10 & .020 & -.051 & LLAREA & .427 & -.459 \\
\hline BLEG11 & .021 & -.009 & LLBREAD & .026 & -.101 \\
\hline BLEG12 & .003 & .017 & LLMAJAX & .210 & .222 \\
\hline BLEG13 & .045 & .038 & LLPERI & .407 & .328 \\
\hline BLEG14 & .048 & -.013 & MEDLAM1 & .020 & -.015 \\
\hline BLEG15 & .004 & -.000 & MEDLAM2 & .181 & .153 \\
\hline BLEG16 & .062 & -.009 & MEDLAM3 & .184 & .149 \\
\hline BLEG17 & .068 & .004 & MEDLAM4 & .080 & .098 \\
\hline \multirow[t]{6}{*}{ BLEG18 } & .003 & -.012 & MEDLAM5 & .082 & .093 \\
\hline & & & MEDLAM6 & .101 & .057 \\
\hline & & & MLAREA & .465 & -.590 \\
\hline & & & MLBREAD & .030 & -.110 \\
\hline & & & MLMAJAX & .200 & .161 \\
\hline & & & MLPERI & .403 & .195 \\
\hline
\end{tabular}

Note: Landmarks and variable identifications are presented in McPeek (1995a) and Stoks et al. (2005b).

yses have shown that all these measures are independent of size in damselflies (McPeek et al. 2001; McPeek 2004).

Again, because our purpose here is to compare the phenotypes of species found in different lake types and in different genera, we take the measures for these four variables in complete isolation and in the presence of the species' native predator as separate phenotypes. We cal- culated the mean of each variable in each treatment for each species and used these in ANOVAs to test for genus and lake type differences.

\section{Evolutionary Character Reconstructions}

Previous studies have considered the evolutionary changes in these sets of phenotypes in Enallagma to be associated 
with the habitat shifts from living with fish to living with large dragonflies (see references for previously published analyses in each section above). Here, we focus on testing adaptive hypotheses about the diversification of Lestes, which requires that we consider both the shifts associated with changing from overwintering as a diapausing egg to overwintering as a larva-the life-history shift—and shifts to new predator habitats. Although the three species with overwintering larvae do not form a well-supported clade, the various phylogenetic hypotheses derived from our molecular data are nonetheless consistent with one life-history shift from overwintering eggs (L. congener is the most basal species) to overwintering larvae and these species subsequently radiating almost immediately after the shift in life history (fig. 3). Because this is the most parsimonious explanation for the evolution of life histories across the genus, we will assume a branching structure that places L. inaequalis, L. vigilax, and L. eurinus together as a clade for the analysis of evolutionary rates.

Also, because the speciation event leading to $L$. vigilax occurred so far in the past, we feel that assuming a model of punctuated evolution in which all character change occurs at the time of speciation is more appropriate. The shift to live with an evolutionarily novel predator would require rapid adaptation by the shifting lineage to coexist with fish. In other words, any adaptation to living with fish by L. vigilax would have been the impetus for speciation and must have occurred rapidly, which justifies a punctuated model of character evolution. Thus, we feel that averaging character change over the entire history of L. vigilax, as a Brownian motion model of character change would assume, is inappropriate. Therefore, for these analyses of character evolution, we set all branch lengths equal to 1.0 .

We are conducting these analyses to test whether phenotypic changes associated with habitat shifts to live with a new predator or a life-history shift are consistent with adaptation. If character change associated with these shifts to new selective regimes were adaptations, we would expect to see accelerated rates of character change on single branches, along which we would predict the habitat or life-history shift to have occurred (Larson and Losos 1996). We applied a modification of Felsenstein's (1985, 1988) method of evolutionary contrasts to isolate character changes on single branches of the phylogeny where these shifts are hypothesized to have occurred (McPeek 1995b). For predator shifts, these branches would be the external branch leading to L. dryas for the shift from living with dragonflies to living in an essentially predator-free environment and the external branch leading to L. vigilax for the shift from living with dragonflies to living with fish (we have no data for L. inaequalis for any of the relevant analyses here, so L. inaequalis is pruned from the tree for these tests). For the life-history shift, the relevant single branch is the one leading to the common ancestor of $L$. inaequalis, L. eurinus, and L. vigilax. (A graphic program written in Java [ver. 1.5, Sun Microsystems] for performing these analyses is available from M. A. McPeek on request.)

We applied these methods to calculate sets of standardized evolutionary contrasts for each variable that was identified in the phenotypic analyses described in the previous sections to differ significantly and in the appropriate direction among either the predator or life-history groups of Lestes. For those identified characters, we tested whether the magnitude of evolutionary change along the single branches on which the habitat shifts were hypothesized to have occurred were significantly larger than the magnitude of evolutionary character change in the rest of the tree. To do this, we compared the absolute values of the standardized evolutionary contrasts on single branches to those in the rest of the tree: the magnitude of a standardized evolutionary contrast is a measure of the rate of evolutionary change in the character along the associated branches on the phylogeny (McPeek 1995b). The unit for this rate is per inferred speciation event. Absolute values of the resulting standardized evolutionary contrasts were analyzed in Hotelling's $T^{2}$ tests (Morrison 1990) to determine whether rates of character change were greater along these single branches, as compared to character change only in the temporary dragonfly ponds. All tests are one-tailed, because we expect evolutionary rates to be increased along these single branches.

\section{Results \\ Phylogenetic Analyses of Lestes}

Maximum likelihood, maximum parsimony, and minimum evolution analyses produced phylogenetic hypotheses that were nearly identical. Results using Modeltest, version 3.06, found that the GTR + I + G model of nucleotide substitution with a shape parameter of 0.42 was the best fit to the data. Using this model and the maximum likelihood criterion, the most likely tree had Lestes congener as the basal Lestes species of those included in the analysis and well-supported branching among the Lestes unguiculatus-Lestes stultus subclade (fig. 2). The three species with overwintering larvae formed another subclade, which was not well supported in the bootstrap analysis. The two most parsimony-informative trees (length 356) also differed only in the branching structure among the three species with overwintering larvae. As a result, the consensus of these two maximum parsimony trees placed these three species as a polytomy with the common ancestor of the L. unguiculatus-L. stultus subclade, and the bootstrap analysis also did not place these three species as a separate 


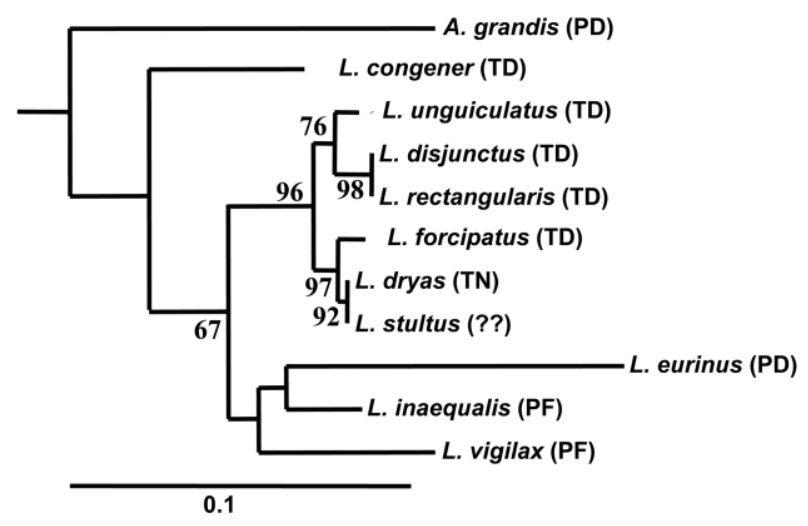

Figure 2: Phylogenetic hypothesis for the North American Lestes damselflies based on maximum likelihood analyses of the $16 \mathrm{~S}$ and ND1 mitochondrial DNA fragments. Bootstrap support values of $>50 \%$ are given on the topologies. Pond permanence is additionally identified as " $\mathrm{P}$ " for permanent and " $T$ " for temporary. In addition, " $F$ " identifies those species that live with fish, "D" identifies those species with dragonflies as their top predators, and "N" identifies species that live in an essentially predator-free environment. The hydroperiod and predator regimes experienced by Lestes stultus are unknown to us.

subclade. Analyses using the minimum evolution criterion found a tree with branching structure identical to that of the maximum likelihood tree and with similar bootstrap support. Analyses of the full data set without $L$. congener were also very similar to the analyses of only ND1 and $16 S$.

\section{Phenotypic Patterns}

Behavior. Enallagma and Lestes species moved for different reasons, but their overall activity levels were not different. In our behavioral experiments, walks in which larvae simply changed their position on the substrate were distinguished from walks to pursue prey. Most walks by Lestes larvae in all three predator treatments were done to pursue prey, whereas Enallagma rarely moved to pursue prey but frequently walked to simply change positions (fig. $3 b$; MANOVA for six walk-and-advance-toward-prey variables: $F=46.79$, df $=6,8, P<.0001$ ). Also, species in both genera that live with fish or dragonfly predators rarely swam, and the frequency of swims did not differ between the genera (fig. $3 a$; MANOVA of three swim variables: $F=1.94, \mathrm{df}=3,11, P>.15)$. However, Lestes dryas, the species that lives in an essentially predator-free habitat, swam $\sim 8$ times more frequently than any other Lestes or Enallagma species (fig. $3 a$; MANOVA of three swim variables: $F=60.03$, df $=3,11, P<.0001$ ).

If all swims, walks, and advances toward prey are combined into one "total moves" variable (fig. $4 a-4 d$ ), a very different picture of the genera emerges. Species that live with different predators differed greatly in their activity in the three predator treatments (fig. $4 a-4 d$; MANOVA results for the six total-move and inactive variables for the PREDATOR main effect: $F=8.06, \mathrm{df}=6,8, P<.005$ ). Species living with dragonflies in both temporary and permanent ponds in both genera moved more in the absence of predators (fig. $4 a ; F=15.48$, df $=1,13, P<.002$ ) and in the presence of fish (fig. $4 b ; F=23.76, \mathrm{df}=1,13$, $P<.0005)$, but the two predator groups moved similar numbers of times in the presence of dragonflies (fig. $4 b$; $F=0.04, \mathrm{df}=1,13, P>.80)$. Fish-lake species also had a much longer inactivity period in the presence of fish than did dragonfly-lake species (fig. $4 d ; F=14.13$, $\mathrm{df}=1,13, P<.003)$, but the two groups did not differ in the longest inactive period in the absence of predators

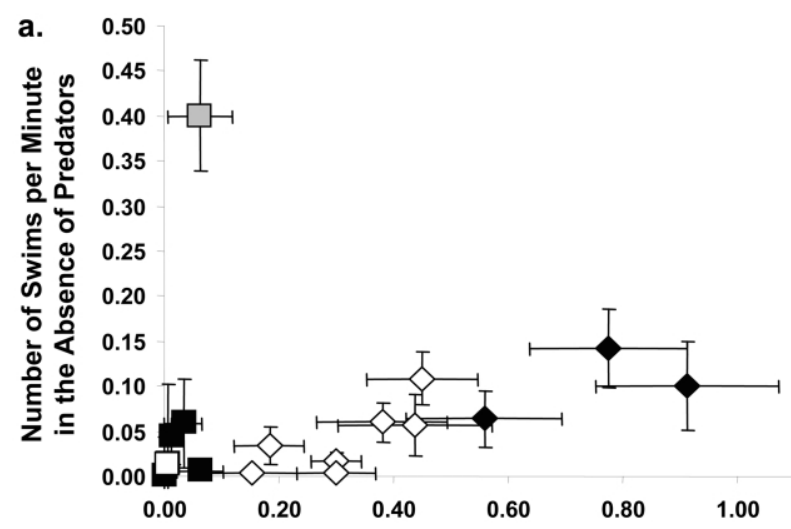

b.

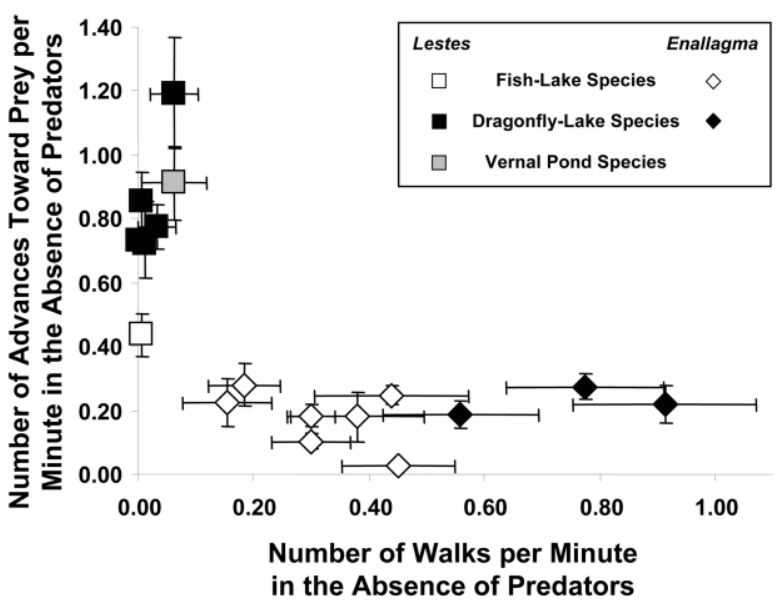

Figure 3: Results of behavioral experiments showing the relationships between the number of swims, advances toward prey, and number of walks per minute in the absence of predators for final instars of Enallagma and Lestes species. Each symbol represents the mean $( \pm 1 \mathrm{SE})$ for one species. Symbols identify the genus and the predator affinity of each species (see inset). 
or the presence of dragonflies (fig. $4 b$, fig. $4 c$; both $P>$ $.10)$. However, the genera did not differ in the number of moves performed or the longest inactive period within trials across the three predator treatments (fig. 4a-4d; MANOVA of the six total-move and inactive variables for the genus main effect: $F=1.89$, df $=6,8, P>.15$; or the genus $\times$ predator interaction: $F=0.44, \mathrm{df}=6,8, P>$ $.80)$.

In contrast to measures of activity, the body masscorrected feeding rates of larvae in these behavioral experiments showed a strong interaction between genus and lake type (fig. $4 e$, fig. $4 f$; MANOVA of the three feeding-rate variables for the genus $\times$ predator interaction: $F=11.04$, $\mathrm{df}=3,11, P<.002)$. This interaction resulted because feeding rate was higher in Lestes than in Enallagma (ANOVA: $F=10.47, \mathrm{df}=1,13, P<.007$ ), but there were no significant differences among the lake type groups (ANOVA: $F=0.33$, df $=1,13, P>.55$ ) or in the interaction between genus and lake type (ANOVA: $F=0.10$, $\mathrm{df}=1,13, P>.75)$ in the absence of predators; feeding rate did not differ between the genera or lake-type groups in the presence of dragonflies (all terms in the ANOVA with $P>.25$ ); and in the presence of fish, the species in dragonfly lakes had higher feeding rates (ANOVA: $F=9.53$, $\mathrm{df}=$ $1,13, P<.009$ ), but the genera did not differ (genus ANOVA: $F=2.19$, df $=1,13, P>.15$; genus $\times$ predator ANOVA: $F=3.67, \mathrm{df}=1,13, P>.05)$.

In contrast, Lestes dryas, the species that lives in an essentially predator-free habitat, on average moved more and was inactive less than any other species (MANOVA of the six total-move and inactive variables comparing $L$. dryas to all other species regardless of genus: $F=3.68$, $\mathrm{df}=6,10, P<.05)$. Lestes dryas also ate prey substantially faster than the average species living with predators (fig. $4 e, 4 f$; MANOVA: $F=8.30, \mathrm{df}=6,26, P<.0001)$. These differences are particularly striking in the presence of dragonflies (fig. 4). Also, L. dryas showed no change in its behavior in the presence or absence of predators (fig. 4; see Stoks and McPeek $2003 a$ for statistical justification of this point).

Morphology. Overall, the principal component (PC) loadings for this study including both Lestes and Enallagma larvae were quite similar to those obtained in an earlier analysis that included only 10 Enallagma species (table 3 ). Not surprisingly, the first PC for each of the three body parts measured was an indicator of overall size of that part (i.e., all loadings positive on PC1 for each structure), and Lestes larvae were on average substantially larger than Enallagma larvae for all three (fig. 5; leg PC1: $F=57.84$, df $=1,15, P<.0001 ;$ abdomen PC1: $F=48.96$, $\mathrm{df}=$ 1, 16, $P<.0001$; lamella PC1: $F=28.56$, df $=1,16, P<$ $.0001)$. This size disparity is why the first PC for each accounted for $>84 \%$ of the total variation in each morphological structure (table 3 ).

Although overall leg size differed greatly between the genera, no predator or genus $x$ predator effects were evident for leg PC1 (both with $P>.10$ ), and no effects were significant for leg PC2 (leg PC2 contrasted the relative lengths of the middle and back legs, all with $P>.25$ ).

Based on the results for abdomen PC2, which contrasts the relative widths (positive loadings) and lengths (negative loadings) of abdominal segments (table 3), Lestes species had on average narrower abdomens for their length than Enallagma species (fig. $5 b ; F=5.56$, df $=1,16$, $P<.05)$, and for both genera, species in fish lakes had narrower abdomens relative to length than species in dragonfly lakes (fig. $5 b ; F=14.39$, df $=1,16, P<.002$ ).

In addition to the overall size difference between the genera, the genera differed in how fish-lake and dragonflylake species differed in lamella size (i.e., lamella PC1, fig. $5 c$; genus $\times$ predator interaction: $F=6.13, \mathrm{df}=1,16$, $P<.03)$. As previous studies have shown, Enallagma species in dragonfly lakes, on average, have larger lamellae than fish-lake Enallagma, even after correcting for overall body size (see also McPeek 1995a, 1999, 2000). In contrast, Lestes species in fish lakes have larger lamellae than dragonfly-lake Lestes (fig. 6c), but this difference is entirely due to the difference in overall body size, since this difference vanishes when lamella PC1 is regressed on abdomen length for only the Lestes species (e.g., ANCOVA of PC1 with abdomen length as the covariate shows no difference between fish-lake and dragonfly-lake Lestes: $F=2.51, \mathrm{df}=1,124, P>.10)$.

Swimming. The least squares means derived from the ANCOVA of swim speed regressed on wet mass for the 20 species of Enallagma and Lestes showed a strong genus $\times$ predator interaction $(F=9.27, \mathrm{df}=1,16, P<$ $.01)$. Swimming speeds of Lestes and Enallagma species in dragonfly lakes were not different (fig. 6; Lestes $25.0 \pm$ $1.4 \mathrm{~cm} / \mathrm{s}$ and Enallagma $28.9 \pm 4.9 \mathrm{~cm} / \mathrm{s}$ [average least squares mean $\pm 1 \mathrm{SD}$ of least squares means for dragonfly-lake species]). However, Enallagma species from fish lakes swam slower than the dragonfly-lake species $(17.2 \pm 5.6 \mathrm{~cm} / \mathrm{s}$ [average least squares mean $\pm 1 \mathrm{SD}$ for fish-lake Enallagma]), whereas Lestes vigilax, the only fishlake Lestes tested, swam faster than the dragonfly-lake group (31.9 cm/s; fig. 6).

Digestive Physiology. Enallagma and Lestes differed greatly in growth and digestive measures (genus effect in MANOVA including all eight response variables: $F=$ 11.98 , df $=2,11, P<.002$ ), but species living with different predators did not differ within the genera (in the same MANOVA including all eight response variables, 


\begin{tabular}{|ccc|}
\hline Lestes & Enallagma \\
$\square$ & Fish-Lake Species & $\diamond$ \\
$\square$ & Dragonfly-Lake Species & $\diamond$ \\
$\square$ & Vernal Pond Species \\
\hline
\end{tabular}

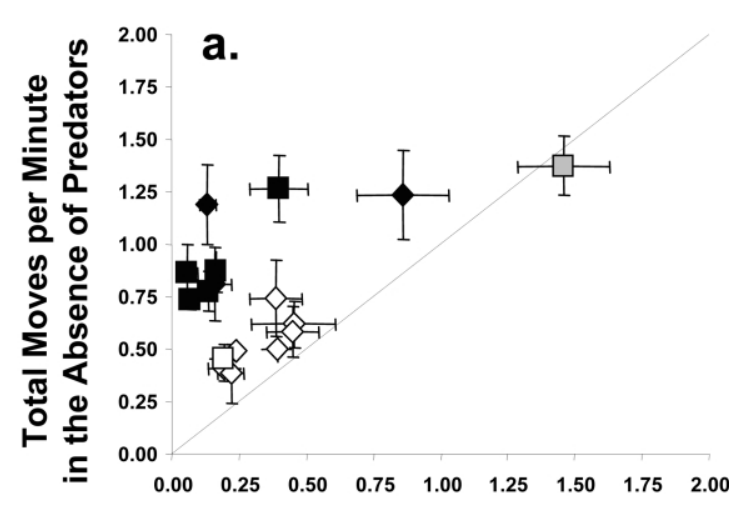

Total Moves per Minute in Presence of Dragonflies
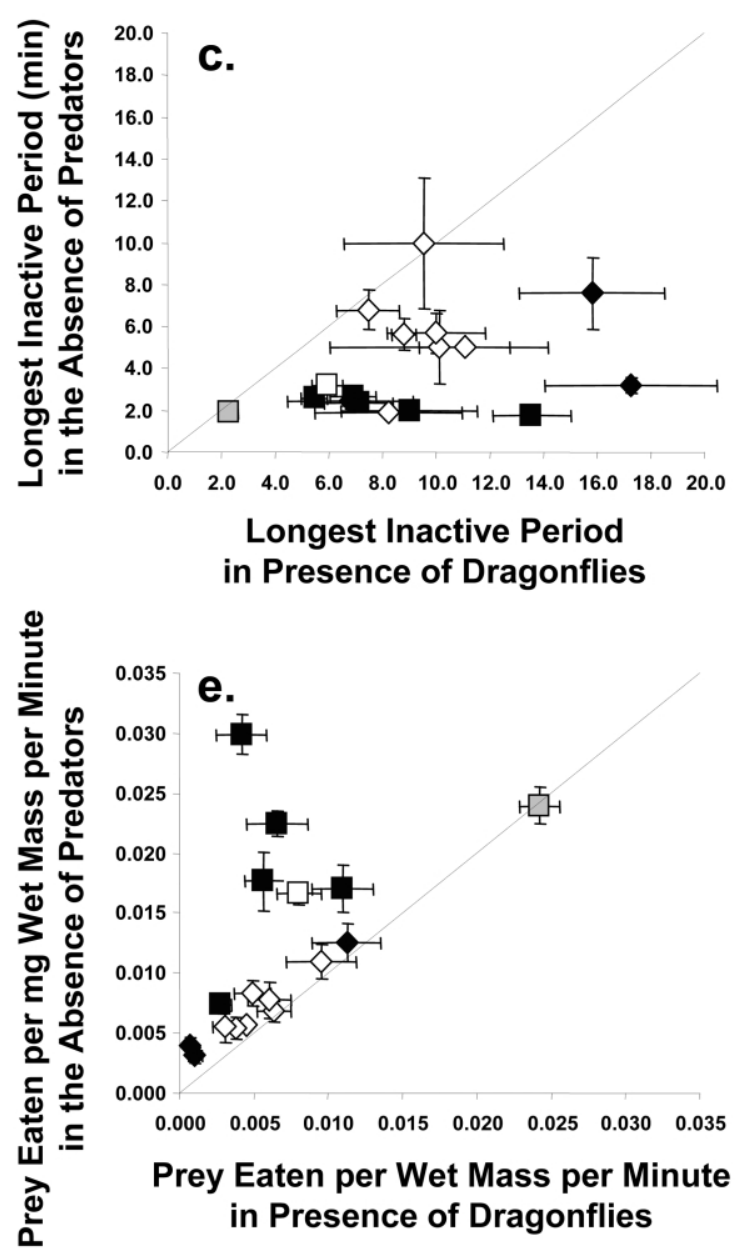

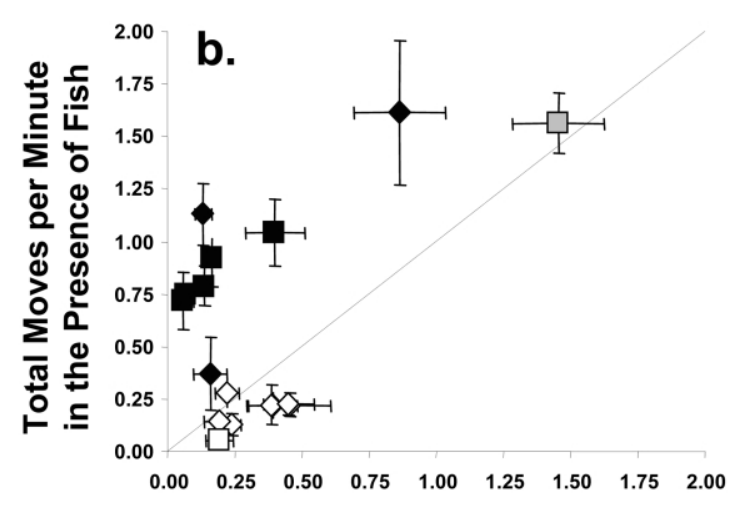

Total Moves per Minute in Presence of Dragonflies
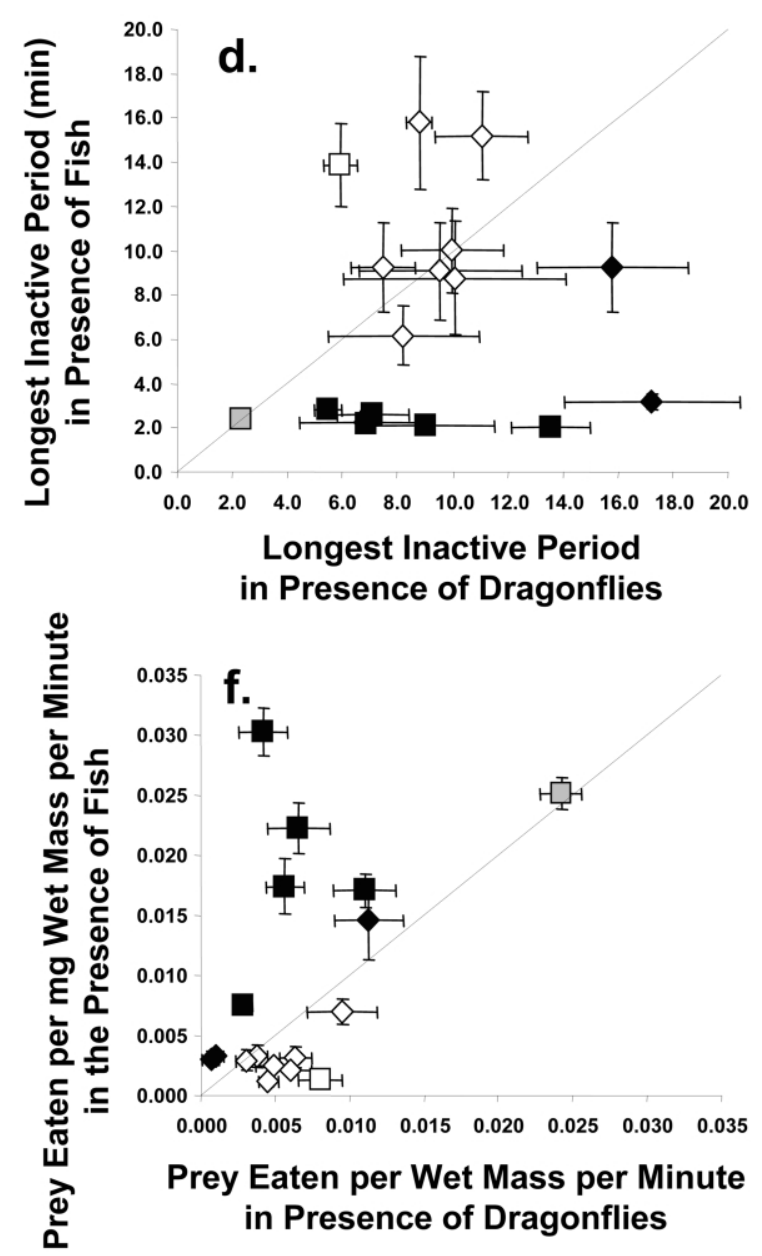
predator: $F=1.28, \mathrm{df}=2,11, P>.30$; genus $\times$ predator: $F=0.09, \mathrm{df}=2,11, P>.90$; fig. 7). In fact, Lestes species were better in every way than Enallagma species: as compared to Enallagma, Lestes species ate more (MANOVA including only the two ingestion variables [fig. 7b]: $F=40.56, \mathrm{df}=2,11, P<.0001)$, assimilated more of what they ingested (MANOVA including only the two assimilation variables [fig. $7 c$ ] : $F=5.99, \mathrm{df}=2,11, P<$ .02 ), produced more with what they assimilated (MANOVA including only the two production variables [fig. $7 d$ ]: $F=57.86, \mathrm{df}=2,11, P<.0001)$, and gained substantially more mass (MANOVA including only the two growth rate variables [fig. $7 a$ ]: $F=11.98, \mathrm{df}=2,11, P<.002$ ).

Lestes dryas, the species that lives in an essentially predator-free habitat, did not differ in this respect from any other Lestes in the absence of predators (fig. 7; MANOVA including all four digestion and growth variables: $F=0.05, \mathrm{df}=4,2, P>.99)$ but was significantly different in the presence of predators from those that live with predators (MANOVA: $F=15.96, \mathrm{df}=4,2, \quad P<.05$ ). Evaluation of the individual metrics suggested that this overall difference was due primarily to $L$. dryas growing significantly faster in the presence of predators $(F=$ $7.74, \mathrm{df}=1,5, P<.04$; univariate tests of the other three variables had $P>.15$ ).

\section{Evolutionary Character Reconstructions}

The only substantial phenotypic differences associated with life histories were that Lestes species with overwintering larvae were substantially larger than those with overwintering eggs (i.e., $\mathrm{PC} 1$ for each morphological structure [fig. 5]). We reconstructed the evolution of these characters on the Lestes phylogeny in analyses that isolated character change along the single branch leading to the assumed common ancestor of Lestes inaequalis, Lestes eurinus, and L. vigilax. When these measures of size are considered together, the rate of character change associated with this life-history shift showed accelerated rates of evolution as compared to change in these characters when no lifehistory shift occurred (Hotelling's $T^{2}$ test including these measures of size as response variables: $F=88.44$, $\mathrm{df}=$ $3,1, P<.05)$.

We also evaluated evolutionary rates of character change associated with the separate shifts from living with dragonfly predators to living with fish (i.e., single branch leading to $L$. vigilax) and to living in essentially predator-free temporary ponds (i.e., single branch leading to L. dryas). All analyses here assume character change along these two single branches and compare change on each of these branches, depending on what shift is being considered, to character change in association with dragonfly predators. When compared to the dragonfly-lake Lestes, L. dryas swam more than any other species, was more active and captured more food in the presence of dragonflies, and moved more in all predator treatments and grew faster in the presence of predators in the digestion experiment. When these variables are considered together, evolutionary contrasts analyses indicate that the rates of evolutionary change in these characters associated with the shift into predator-free temporary ponds was substantially accelerated, as compared to change in these characters in the dragonfly-lake habitat (an overall Hotellings $T^{2}$ test could not be performed on the standardized evolutionary contrast values because more response variables than observations would be included, but all characters are significant at $P<.02$ in separate univariate tests, which implies that the overall combined test would also be significant if it could be performed).

Lestes vigilax differed from the dragonfly-lake Lestes primarily in being less active in the presence of fish (fig. 4). The rates of evolutionary change in the three behavioral variables measured in the presence of fish were significantly accelerated along the single external branch for $L$. vigilax (i.e., the branch on which we hypothesize the habitat shift from dragonfly lakes to fish lakes occurred; Hotelling's $T^{2}$ test: $F=2,136.4$, df $=3,1, P<.01$ ). (Lestes vigilax also swam substantially faster than the other species, but this phenotypic difference could not have played a direct role in their adaptation to living with fish [see "Discussion"]. Therefore, we do not evaluate the evolutionary rate of change in swimming speed.)

\section{Discussion}

\section{Diversification and Adaptation}

These integrated ecological and evolutionary studies have provided us with a comprehensive historical hypothesis for the diversification and adaptation of Enallagma and Lestes along the pond permanence gradient in eastern North America. Figure 8 summarizes the hypothesized habitat location of the last common ancestor (LCA) for each genus and the sequence of habitat shifts as their di-

Figure 4: Relationships between the presence of fish or dragonflies and $(a, b)$ the number of moves per minute, $(c, d)$ the longest inactive period, and $(e, f)$ the number of prey eaten per milligram wet mass per minute in the absence of predators for final instars of Enallagma and Lestes species. Each symbol represents the mean $( \pm 1 \mathrm{SE})$ for one species. Symbols are identified in the inset key. The dashed line in each panel identifies the $1: 1$ relationship between the two axes. 


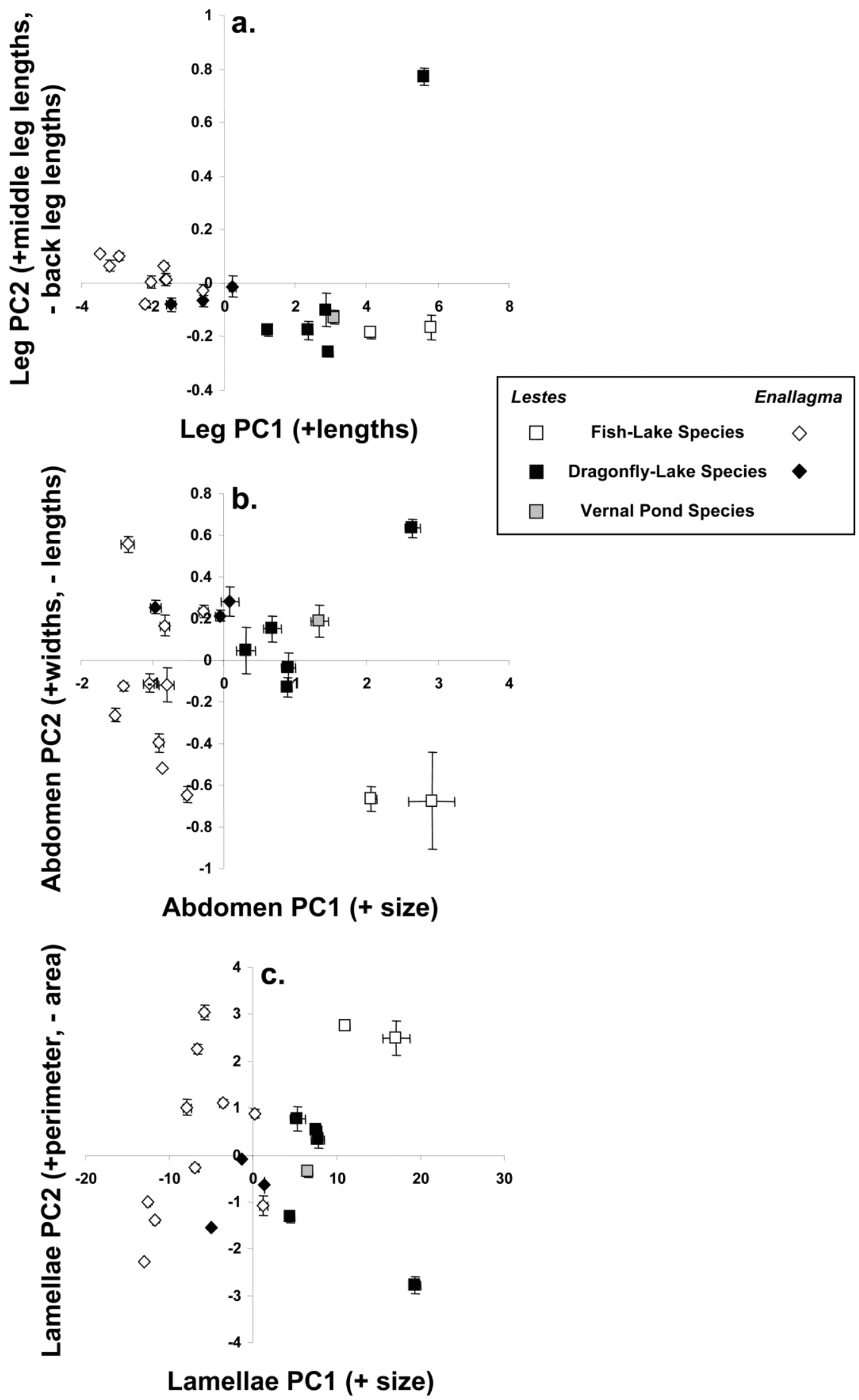


versification filled the gradient. Previous phylogenetic analyses suggest that Enallagma's LCA occupied fish lakes about 10-15 million years ago (McPeek and Brown 2000; Turgeon et al. 2005; using Brower's [1994] molecular clock estimate for CO mtDNA sequences). Given the great similarity among the phylogenetically diverse fish-lake Enallagma species examined in this study (see figs. 3-7), we infer that the Enallagma LCA would have had phenotypic properties that lie somewhere among the phenotypes of today's fish-lake Enallagma: (1) directly developing eggs and overwintering as aquatic larvae; (2) inactivity in the absence of predators and reaction to the presence of both fish and dragonflies by reducing activity and responsiveness to prey (fig. 4; McPeek 1990a; Stoks et al. 2003); (3) slow swimming and lack of flight when attacked by fish or dragonflies (fig. 6; McPeek et al. 1996; McPeek 1999, 2000); and (4) relatively small size (fig. 5) and slow growth in the absence of predators and growth slowed even further when either fish or dragonflies were present because of physiological stress responses (fig. 7; McPeek et al. 2001; McPeek 2004; Stoks et al. 2005a). This taxon diversified at a relatively steady rate until very recently and then explosively radiated over the past 250,000 years (McPeek and Brown 2000; Turgeon et al. 2005).

The LCA of the North American Lestes appears to date to a more recent time and appears to have occupied a different part of the pond permanence gradient. Lestes congener, a temporary-dragonfly-pond species, is well supported as the basal Lestes in our analyses, and parsimony reconstructions of habitat affinity also support temporary dragonfly ponds as the habitat of the Lestes LCA (fig. 8). Because of the phenotypic similarity among extant temporary-dragonfly-pond Lestes, we infer that the Lestes LCA was phenotypically similar to them: (1) laying desiccation-resistant, diapausing eggs; (2) active in the absence of predators and responding to dragonflies but not fish by decreasing activity (fig. 4; Stoks and McPeek 2003a); (3) using fast swims as an evasive antipredator tactic (fig. 6; Stoks and McPeek 2003a); and (4) relatively large size (fig. 5) and fast growth in the absence of predators but somewhat slower growth in the presence of dragonflies due to behavioral and physiological stress responses (fig. 7; Stoks and McPeek 2003a). Fast growth permitted rapid completion of the larval phase after the eggs hatched in the spring (Stoks et al. 2005c, 2006).

The first shift to colonize a new part of the pond permanence gradient appears to have occurred when Lestes
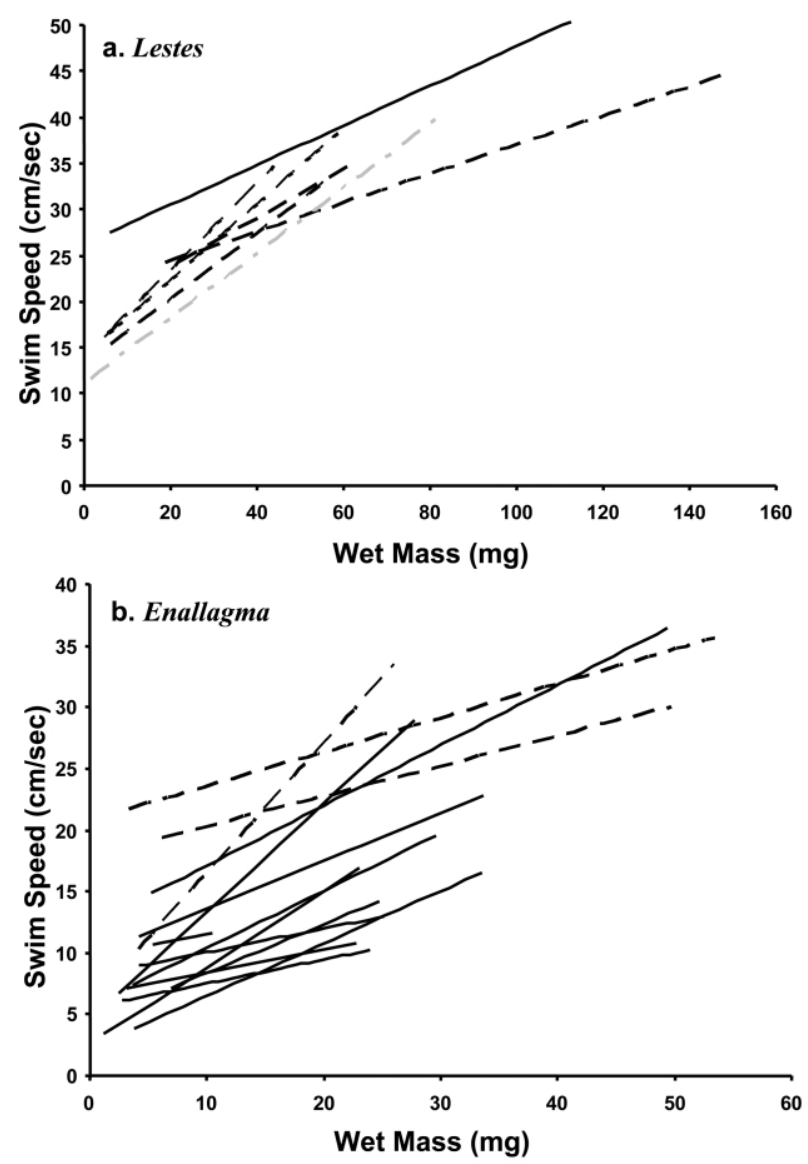

Figure 6: Fastest swimming speeds recorded for (a) Lestes and (b) Enallagma larvae over a large range of sizes. Because of the great number of points, only the least squares regression line for each species is shown. Solid lines represent regressions for species with fish, dashed lines are for species in temporary and permanent dragonfly ponds, and the gray dashed line is for Lestes dryas in temporary ponds with no predators.

evolved directly developing eggs (fig. 8). Although the relationships of the species with overwintering larvae and the LCA of the Lestes unguiculatus-Lestes stultus clade (fig. 2) are poorly supported, the most parsimonious interpretation of the evolution of egg diapause is still that one lineage evolved directly developing eggs from a diapausingegg species to have an overwintering larva in the life history and that this lineage rapidly diversified soon thereafter to produce the three extant directly developing species (fig. 8). Using the average genetic distances among species

Figure 5: Principal component (PC) ordinations of the morphological features of the $(a)$ legs, $(b)$ abdomens, and $(c)$ caudal lamellae for final instars of Enallagma and Lestes species. PC loadings for each axis are given in table 3. Each symbol represents the mean PC score ( \pm 1 SE) for one species. Symbols are identified in the inset key. 


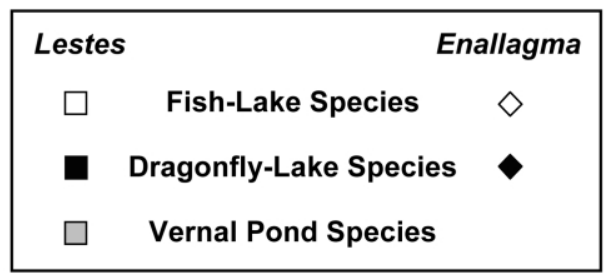

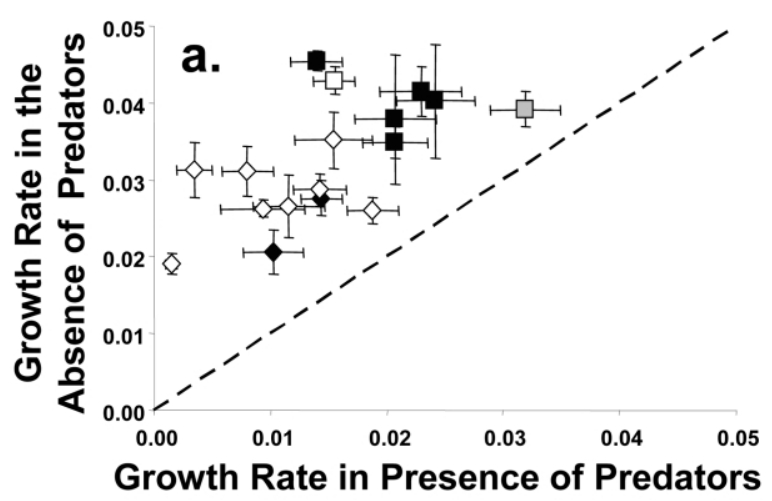

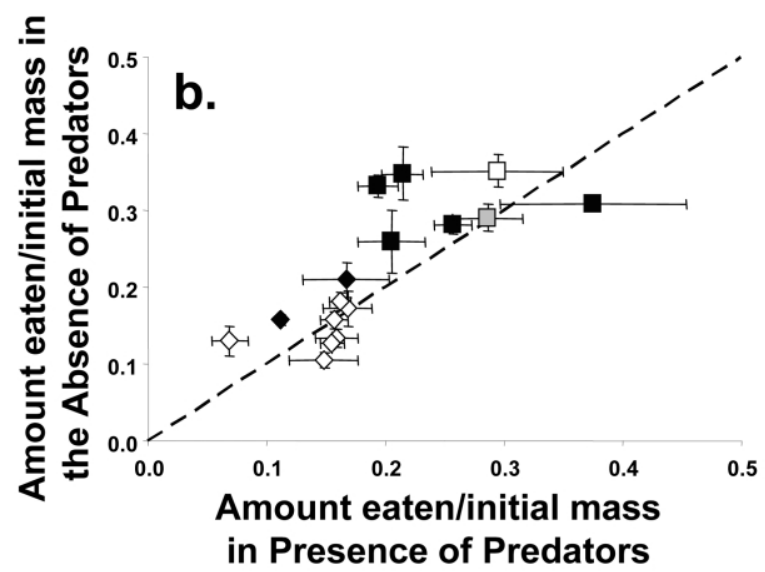

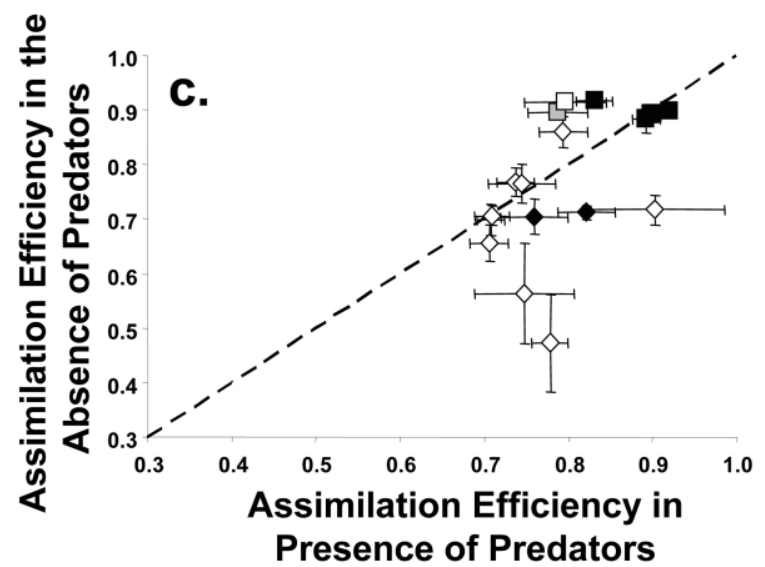

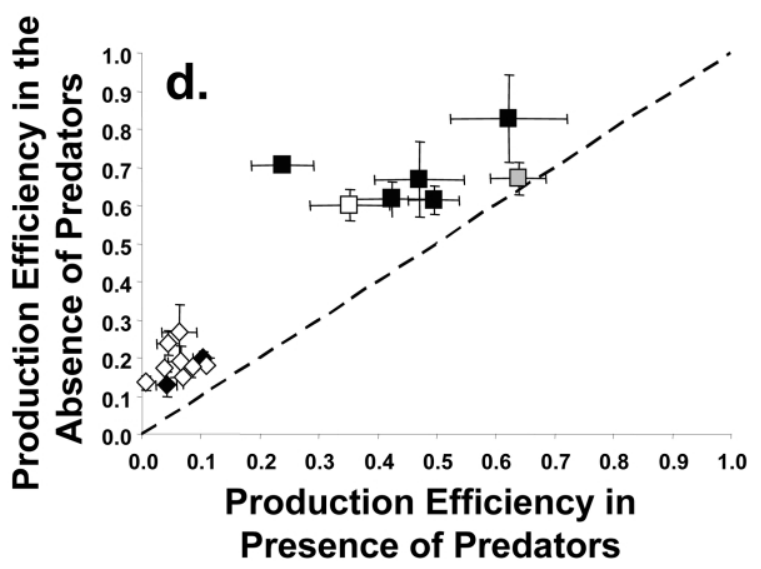

Figure 7: Relationships between $(a)$ growth rate, $(b)$ ingestion, $(c)$ assimilation efficiency, and $(d)$ production efficiency for larvae of Enallagma and Lestes species over a large size range raised for 4 days in the presence or absence of their natural predators. Each symbol represents the mean $( \pm 1$ SE) for one species. Symbols are identified in the inset key. The dashed line in each panel identifies the $1: 1$ relationship between the two axes.

based on the CO mtDNA fragment (so that genetic distances are comparable to our previous estimates for Enallagma; Brown et al. 2000; McPeek and Brown 2000; Turgeon et al. 2005), we estimate that these events occurred about 6-8 million years ago. The exact date is not as critical as the fact that it was several million years ago and that the extant permanent-water species are all relatively old. This invasion of permanent waters produced Lestes species in both fish and dragonfly lakes. This life-history shift was accompanied by a great increase in body size at metamorphosis, primarily because of a greatly extended larval period, since rates of mass gain are not different between temporary- and permanent-pond species (fig. 7).

Little else appears to have changed for Lestes eurinus, the species derived in permanent dragonfly ponds, because it does not differ in behavior- or growth-related variables from temporary-dragonfly-pond species. Today, females of temporary-dragonfly-pond species lay eggs in permanent dragonfly ponds, and these eggs readily hatch in the spring to produce large populations of very small instars of these species (Stoks and McPeek 2003b). These populations are continually extirpated by $L$. eurinus predation in a few 


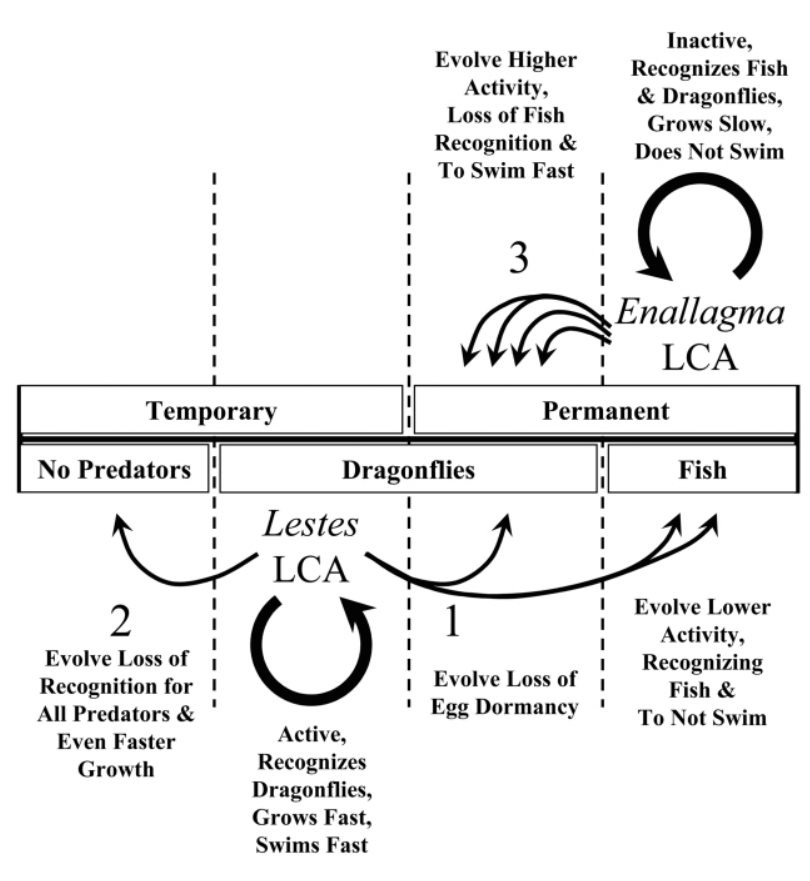

Figure 8: Summary of the hypotheses for the diversification of Enallagma and Lestes along the pond permanence/predation gradient. "Enallagma LCA" and "Lestes LCA" identify the habitats in which the last common ancestor of each genus were hypothesized to have lived. Numbered arrows between habitats identify the order of hypothesized adaptive habitat shifts along the gradient, and text associated with each arrow identifies the major phenotypic changes that occurred with each habitat shift. Finally, the circular arrows next to the LCAs symbolize that in both genera, most diversification apparently occurred in the ancestral habitat.

weeks, because L. eurinus are penultimate and final instars when these other species are just hatching. This great size disparity makes L. eurinus a voracious intraguild predator of these newly hatching larvae (Stoks and McPeek 2003b). Before L. eurinus arose, whatever temporary-dragonflypond Lestes existed probably occupied both temporary and permanent dragonfly ponds. Thus, we infer that advent of $L$. eurinus must have caused a distributional contraction of Lestes species with diapausing eggs to occupy only temporary ponds.

The invasion of fish lakes at about the same time produced Lestes vigilax and Lestes inaequalis. This apparently adaptive habitat shift, based on the evolutionary contrasts analyses, was accomplished primarily by evolving to recognize fish as predators. Lestes vigilax recognizes fish as predators and shows strong behavioral and physiological responses to their presence (figs. 4, 7). Lestes vigilax, like fish-lake Enallagma species, typically tries no evasive maneuvers against attacking predators, whereas those that live with large dragonflies most frequently swim away from attacking predators (Stoks and McPeek 2003a). Thus, our finding that $L$. vigilax is the fastest-swimming Lestes (fig. 7) is of no ecological significance, since swimming has no performance utility to them in nature. Today, L. vigilax co-occurs with fish-lake Enallagma species across eastern North America from the Gulf of Mexico to southern Canada and from the Atlantic to the Great Plains (Johnson and Crowley 1980; McPeek 1990b, 1998; Donnelly 2004). Given our molecular clock estimates of origination dates, we infer that $L$. vigilax must have been invading and adapting to a habitat that already contained many Enallagma species. Moreover, this adaptation resulted in strong convergence with these fish-lake Enallagma in overall activity levels and behavioral and physiological responses to fish (fig. 4; and note deviations from 1:1 line in fig. 7).

In contrast, the faster growth rates of permanent-pond Lestes relative to their Enallagma compatriots appears to be a residual consequence of their being derived from temporary-pond lineages. This conclusion illustrates the importance of a phylogenetic perspective to understanding the development of community structure. Because growth rate is an important ecological performance character, one might have concluded from a nonphylogenetic, phenotypic analysis that this growth difference resulted from past divergence to permit their current coexistence. However, this phylogenetic analysis shows that growth rates have not diverged within the genera and are simply inherited from past ancestors that occupied a different habitat where fast growth was critical.

More recently, Lestes has invaded the predator-free temporary-pond environment to produce the extant Lestes dryas (fig. 8). Again applying Brower's (1994) molecular clock estimate to the genetic distance for CO between $L$. dryas and Lestes forcipatus, we obtain an estimate of about 1-1.5 million years ago. The main changes associated with this habitat shift were the loss of the ability to recognize dragonflies as threatening predators. These ponds are an essentially predator-free environment for Lestes, and so the loss of predator recognition abilities is not surprising.

Finally, the most recent expansion along the gradient was the invasion of permanent dragonfly ponds by $E n$ allagma within the past 110,000 years (fig. 8; McPeek and Brown 2000; Turgeon et al. 2005). Extensive phylogenetic and phylogeographic sampling showed that the four extant dragonfly-lake Enallagma species arose from three independent habitat shifts during the explosive radiations associated with recent glacial cycles (Turgeon et al. 2005). These lineages adapted to the new predation regime by evolving behavioral, morphological, and biochemical features to make them faster swimmers (McPeek 1995a, 1999, 2000; McPeek et al. 1996); greater activity in the absence of predators; and the loss of recognition of fish as predators (Stoks et al. 2003). Our analyses highlight that these features show striking convergence to the phenotypes of Lestes 
species that live in these same ponds with dragonflies. Moreover, these three Enallagma lineages were independently invading and adapting to a food web of which $L$. eurinus had been a member for millions of years.

\section{Implications for the Development of Community Structure}

Ecological theory predicts that species must be different from one another in specific ways to coexist for long periods of time (e.g., Roughgarden 1974; Chesson 2000), and we have a number of examples of how diversification fosters coexistence within an ecological setting (e.g., Grant 1986; Losos 1990; Schluter and McPhail 1993). But when considering the full scope of differences among communities along an ecological gradient, theory also predicts that species living at any one point on that gradient should be more similar to one another than they are to species at other points along the gradient (Leibold 1998). Many taxa segregate along the pond permanence gradient based on predator distributions (see reviews in Wellborn et al. 1996 and Wissinger et al. 1999), implying that trade-offs in mortality to different predator types primarily shape species distributions along this gradient. Thus, the convergence of the genera onto the same adaptive solutions to deal with fish and dragonfly predation is not surprising and supports this implication. This also implies that only a limited number of phenotypic solutions are available to the problems posed by any particular ecological setting.

The intimate association of Enallagma and Lestes species in the fish lakes of eastern North America for the past several million years also implies that coexistence mechanisms perpetuate their association and probably do so in permanent dragonfly lakes as well. Coexisting species must still differ in ways that make them differentially successful in at least some ecological performance capabilities (Chesson 2000). Species in the two genera are nearly indistinguishable in traits that shape their interactions with predators; phenotypically they are indistinguishable in overall levels of activity, which should make them similarly apparent to predators, they both respond to attacking predators in similar ways (Stoks and McPeek 2003a), and dragonfly-lake species in the two genera have indistinguishable swimming capabilities (fig. 6). Consistent with this, quite similar mortality rates are imposed by predators on Lestes and Enallagma species (cf. mortality rates in predator treatments in McPeek 1990b, 1998; Stoks and McPeek 2003b). Lestes species have a substantial advantage in consuming resources and converting them into their own biomass (fig. 7) - a legacy of their evolutionary descent from a temporary-pond ancestor. Therefore, we predict that Lestes species should be better resource competitors in both permanent habitat types. Their greater size should also make them intraguild predators of Enallagma species. However, the countervailing advantages that Enallagma species must possess if they truly coexist are not apparent. We are undertaking ecological studies of various possible coexistence mechanisms to explore how they may have persisted together in North American lakes for the past several million years.

Their reciprocal adaptation to waters dominated by fish and dragonfly predators also shows that the phenotypes possessed by each genus in each habitat are adaptations to living with those predators. In such retrospective analyses as this, an adaptation can be identified only when a phenotypic change can be associated with a change in selective environment. This means that ancestral phenotypes cannot be ascribed to any selective benefit. However, the convergence of each genus when invading to live with a new predator onto the inferred ancestral phenotypes of the other genus allow us here to identify the ancestral phenotypes of each genus as adaptations as well. Thus, we can confidently say that lower activity and not swimming away from attacking predators are adaptations to living with fish and that higher activity and swimming away from attacking predators are adaptations for living with dragonflies in both genera.

These reciprocal habitat shifts also provide insights into how changes in selection regime alter the selection pressures on various traits and how these changes influence phenotypic diversity. One of the primary adaptive changes in the three Enallagma lineages that shifted from fish to dragonfly waters was a behavioral shift to use swimming to evade attacking predators (McPeek et al. 1996; McPeek 1999, 2000). This behavioral shift in turn focused selection pressures on morphological and physiological traits to increase swimming speed (i.e., increasing lamellae size and abdominal muscle mass [McPeek 1995a, 1997, 2000; McPeek et al. 1996] and increasing arginine kinase activity to increase ATP recharge capacity [McPeek 1999, 2000]). Because these selection pressures are conditioned on the use of swimming as an evasive tactic against predators, these characters would have been neutral with respect to swimming in the ancestral environment. In contrast, when the Lestes lineage(s) shifted from dragonfly to fish waters, they shifted behaviors to reduce activity and to stop swimming away from attacking predators (Stoks and McPeek 2003a). This shift in behavior would remove selection for faster swimming speed, thus removing selection pressures on morphological and physiological traits that influence swimming speed. Consistent with this, we saw no decrease in swimming speed and no change in lamella morphology associated with the Lestes shift from dragonfly to fish lakes (figs. 6, 7) and, in results not reported here, no differences in arginine kinase activity among any Lestes species (cf. the large differences between fish- and dragonfly-lake $E n$ allagma species; McPeek 1999, 2000). Thus, reciprocal 
habitat shifts will not necessarily result in reciprocal changes in phenotypes, because removing a selection pressure is not the evolutionary opposite of adding that selection pressure.

Our phylogenetic analyses also provide new insights for further inquiry into the development of species richness patterns along the pond permanence gradient. Both genera have their highest species richness in their inferred ancestral habitat: Enallagma in fish lakes and Lestes in temporary dragonfly ponds (fig. 1). Over the past 10-15 million years, Enallagma diversification in fish lakes has generated many locally and regionally co-occurring species, but the four extant permanent-dragonfly-lake species all seem to be less than 110,000 years old (Brown et al. 2000; McPeek and Brown 2000; Turgeon et al. 2005). One interpretation of this disparity in Enallagma species numbers is simply that Enallagma has occupied the permanentdragonfly-pond habitat for less time. However, the four extant dragonfly-pond Enallagma may be only the latest Enallagma lineages to recolonize this habitat, since extinct lineages are invisible to systematic analyses. If this were true, the disparity in Enallagma species richness would be due more to the difference in diversification rates between the two habitats: perhaps Enallagma extinction rates have been higher in permanent dragonfly ponds. No matter what interpretation is developed for Enallagma, it would not seem to apply to Lestes in those same habitats, since Lestes species richness seems to have not changed since these lineages first colonized these very same habitats millions of years ago (fig. 3). Even though these two genera have interacted in the ecological webs of permanent waters for millions of years, whatever biogeographic, climatic, and macroevolutionary forces have fostered diversification in Enallagma have not fostered comparable diversification in Lestes. Lestes diversification in North America has been primarily restricted to the temporary-dragonfly-pond habitat.

This comparison suggests that nonecological features of component taxa may be more important to determining patterns of species richness along environmental gradients than the ecological processes influencing the coexistence of taxa. Theoretical explanations of species richness explore the number of coexisting species that can be maintained in a system based on local species interactions and migration among local communities (e.g., MacArthur 1972; Rosenzweig 1995; Tokeshi 1999; Chesson 2000). We have argued that and are beginning to test whether sexual selection has played a substantial role in the diversification of Enallagma species in fish lakes. Perhaps their breeding systems differ in ways that make the generation of reproductive isolation more likely in Enallagma. Or, perhaps, differences in dispersal capabilities have led to greater levels of population differentiation in Enallagma that have in turn fostered differential diversification rates in the two genera. Other mechanisms that do not involve coexistence could also influence this difference in diversification along the gradient. If such processes as sexual selection or dispersal primarily determine patterns of species richness among component taxa within any particular community, explanations of species numbers based on local coexistence rules may be largely irrelevant.

This historical analysis of the construction of the damselfly assemblages in North American ponds and lakes is possible only through the integration of many different types of studies. The results of field experiments have identified the species interactions that shape mortality and growth of damselfly larvae and thus have pointed us to critical features of the phenotypes of these interacting species. Functional studies of these phenotypes have revealed the mechanisms shaping ecological performance and in turn fitness relationships in the different habitats. Systematics studies have provided a historical outline of the major steps in this construction process. Finally, comparative analyses of these important phenotypes on this historical outline have identified the major adaptive transitions that have constructed the biological communities we study today. This process has also identified critical ecological features of the system that warrant further analysis (e.g., specific features of the mechanisms permitting Enallagma and Lestes coexistence) and other features of the system where mechanisms outside of the normal disciplinary boundaries of community ecology must be considered (e.g., nonecological mechanisms promoting or retarding diversification). The hypotheses that one is willing to entertain as possible explanations for testing must be determined by attempts to reconcile various aspects of the biology of the system and not simply by the a priori theoretical metaphors constructed within the artificial walls of scientific disciplines. Ultimately, results and theories must be reconciled across disciplinary boundaries, because all these various disciplines are-after all-studying the same nature.

\section{Acknowledgments}

We would like to thank R. Behrstock, S. Dunkle, and T. Manolis for supplying Lestes specimens. This work was supported by National Science Foundation grants IBN0130021 and DEB-0516104 to M.A.M. In addition, R.S. was supported by a Francqui Foundation Fellowship in association with the Belgian-American Educational Foundation (BAEF), a postdoctoral fellowship, travel grants, and research grant G.0.269.04 from the Fund for Scientific Research Flanders (FWO), and research fund OT/04/23 from the Katholieke Universiteit Leuven. We would also 
like to thank the American Society of Naturalists for giving us this opportunity to present our work.

\section{Literature Cited}

Baker, R. L., and H. F. Clifford. 1981. Life cycles and food of Coenagrion resolutum and Lestes disjunctus disjunctus (Lestidae: Odonata) populations from the boreal forest of Alberta, Canada. Aquatic Insects 3:179-191.

Baker, R. L., C. M. Elkin, and H. A. Brennan. 1999. Aggressive interactions and risk of fish predation for larval damselflies. Journal of Insect Behavior 12:213-223.

Brower, A. V. Z. 1994. Rapid morphological radiation and convergence among races of the butterfly Heliconius erato, inferred from patterns of mitochondrial DNA evolution. Proceedings of the National Academy of Sciences of the USA 91:6491-6495.

Brown, J. M., M. A. McPeek, and M. L. May. 2000. A phylogenetic perspective on habitat shifts and diversity in the North American Enallagma damselflies. Systematic Biology 49:697-712.

Chesson, P. 2000. Mechanisms of maintenance of species diversity. Annual Review of Ecology and Systematics 31:343-366.

Diamond, J. M. 1975. Assembly of species communities. Pages 342444 in M. L. Cody and J. M. Diamond, eds. Ecology and evolution of communities. Belknap, Cambridge, MA.

Donnelly, T. W. 2004. Distribution of North American Odonata. III. Calopterygidae, Lestidae, Coenagrionidae, Protoneuridae, Platystictidae, with data sources and bibliography. Bulletin of American Odonatology 8:33-99.

Duffy, W. G. 1994. Demographics of Lestes disjunctus (Odonata: Zygoptera) in a riverine wetland. Canadian Journal of Zoology 72: 910-917.

Elkin, C. M., and R. L. Baker. 2000. Lack of preference for lowpredation-risk habitats in larval damselflies explained by costs of intraspecific interactions. Animal Behaviour 60:511-521.

Felsenstein, J. 1985. Phylogenies and the comparative method. American Naturalist 125:1-15.

. 1988. Phylogenies and quantitative characters. Annual Review of Ecology and Systematics 19:445-471.

Fukami, T. 2004. Community assembly along a species pool gradient: implications for multiple-scale patterns of species diversity. Population Ecology 46:137-147.

Gardner, A. E. 1952. The life history of Lestes dryas Kirby (Odonata). Entomologist's Gazette 3:4-26.

Gilpin, M. E. 1975. Stability of feasible predator-prey systems. Nature 254:137-139.

Gower, J. L., and E. J. Kormondy. 1963. Life history of the damselfly Lestes rectangularis with special reference to seasonal regulation. Ecology 44:398-402.

Grant, P. R. 1986. Ecology and evolution of Darwin's finches. Princeton University Press, Princeton, NJ.

Harmon, L. J., J. J. Kolbe, J. M. Cheverud, and J. B. Losos. 2005. Convergence and the multidimensional niche. Evolution 59:409421.

Henry, C. S., M. L. M. Wells, and C. M. Simon. 1999. Convergent evolution of courtship songs among cryptic species of the Carnea group of green lacewings (Neuroptera: Chrysoperla). Evolution 53:1165-1179.

Holt, R. D., J. P. Grover, and D. Tilman. 1994. Simple rules for interspecific dominance in systems with exploitative and apparent competition. American Naturalist 144:741-771.
Hubbell, S. P. 2001. The unified neutral theory of biodiversity and biogeography. Princeton University Press, Princeton, NJ.

Ingram, B.R. 1976. Life histories of three species of Lestidae in North Carolina, United States (Zygoptera). Odonatologica 5:231-244.

Jackson, J. B. C., and A. H. Cheetham. 1994. Phylogeny reconstruction and the tempo of speciation in cheilostome Bryozoa. Paleobiology 20:407-423.

Jödicke, R. 1997. Die Binsenjungfern und Winterlibellen Europas. Westarp, Heidelberg.

Johnson, D. M., and P. H. Crowley. 1980. Habitat and seasonal segregation among coexisting odonate larvae. Odonatologica 9:297308 .

Kambhampati, S., and P. T. Smith. 1995. PCR primers for amplification of four insect mitochondrial gene fragments. Insect Molecular Biology 4:233-236.

Kaneshiro, K. Y., and C. R. B. Boake. 1987. Sexual selection and speciation: issues raised by Hawaiian Drosophila. Trends in Ecology \& Evolution 2:207-212.

Kurtén, B., and E. Anderson. 1980. Pleistocene mammals of North America. Columbia University Press, New York.

Larson, A., and J. B. Losos. 1996. Phylogenetic systematics of adaptation. Pages 187-220 in M. R. Rose and G. V. Lauder, eds. Adaptation. Academic Press, San Diego, CA.

Leibold, M. A. 1996. A graphical model of keystone predators in food webs: trophic regulation of abundance, incidence, and diversity patterns in communities. American Naturalist 147:784-812.

- 1998. Similarity and local coexistence of species from regional biotas. Evolutionary Ecology 12:95-110.

Leibold, M. A., and M. A. McPeek. 2006. Coexistence of the niche and neutral perspectives in community ecology. Ecology 87:13991410.

Loreau, M., and N. Mouquet. 1999. Immigration and the maintenance of local species diversity. American Naturalist 154:427-440.

Losos, J. B. 1990. A phylogenetic analysis of character displacement in Caribbean Anolis lizards. Evolution 44:558-569.

- 1992. The evolution of convergent structure in Caribbean Anolis communities. Systematic Biology 41:403-420.

Losos, J. B., T. R. Jackman, A. Larson, K. de Queiroz, and L. Rodriguez-Schettino. 1998. Contingency and determinism in replicated adaptive radiations of island lizards. Science 279:2115-2118.

Lutz, P. E. 1968a. Effects of temperature and photoperiod on larval development in Lestes eurinus Say (Odonata: Lestidae). Ecology 49:637-644.

1968b. Life-history studies on Lestes eurinus Say (Odonata). Ecology 49:576-579.

Lutz, P. E., and A. R. Pittman. 1968. Oviposition and early developmental stages of Lestes eurinus (Odonata: Lestidae). American Midland Naturalist 80:43-51.

MacArthur, R. H. 1972. Geographical ecology. Harper \& Row, New York.

McPeek, M. A. 1990a. Behavioral differences between Enallagma species (Odonata) influencing differential vulnerability to predators. Ecology 71:1714-1726.

- 1990b. Determination of species composition in the Enallagma damselfly assemblage of permanent lakes. Ecology 71:8398 .

1995a. Morphological evolution mediated by behavior in the damselflies of two communities. Evolution 49:749-769.

. 1995b. Testing hypotheses about evolutionary change on 
single branches of a phylogeny using evolutionary contrasts. American Naturalist 145:686-703.

. 1996. Trade-offs, food web structure, and the coexistence of habitat specialists and generalists. American Naturalist 148(suppl.):S124-S138.

- 1997. Measuring phenotypic selection on an adaptation: lamellae of damselflies experiencing dragonfly predation. Evolution 51:459-466.

. 1998. The consequences of changing the top predator in a food web: a comparative experimental approach. Ecological Monographs 68:1-23.

- 1999. Biochemical evolution associated with antipredator adaptation in damselflies. Evolution 53:1835-1845.

- 2000. Predisposed to adapt? clade-level differences in characters affecting swimming performance in damselflies. Evolution 54:2072-2080.

- 2004. The growth/predation-risk trade-off: so what is the mechanism? American Naturalist 163:E88-E111.

McPeek, M. A., and J. M. Brown. 2000. Building a regional species pool: diversification of the Enallagma damselflies in eastern North America. Ecology 81:904-920.

McPeek, M. A., and R. Gomulkiewicz. 2005. Assembling and depleting species richness in metacommunities: insights from ecology, population genetics and macroevolution. Pages 355-373 in M. A. Leibold, M. Holyoak, and R. D. Holt, eds. Metacommunities: spatial dynamics and ecological communities. University of Chicago Press, Chicago.

McPeek, M. A., A. K. Schrot, and J. M. Brown. 1996. Adaptation to predators in a new community: swimming performance and predator avoidance in damselflies. Ecology 77:617-629.

McPeek, M. A., M. Grace, and J. M. L. Richardson. 2001. Physiological and behavioral responses to predators shape the growth/ predation risk trade-off in damselflies. Ecology 82:1535-1545.

Mendelson, T. C., and K. L. Shaw. 2005. Sexual behavior: rapid speciation in an arthropod. Nature 433:375-376.

Morrison, D. F. 1990. Multivariate statistical methods. 3rd ed. McGraw Hill, New York.

Mouquet, N., and M. Loureau. 2002. Coexistence in metacommunities: the regional similarity hypothesis. American Naturalist 159: $420-426$.

- 2003. Community patterns in source-sink metacommunities. American Naturalist 162:544-557.

Mouquet, N., P. Munguia, J. M. Kneitel, and T. E. Miller. 2003. Community assembly time and the relationship between local and regional species richness. Oikos 103:618-626.

Paulson, D. R., and C. E. Jenner. 1971. Population structure in overwintering larval Odonata in North Carolina in relation to adult flight season. Ecology 52:96-107.

Pierce, C. L., Crowley, P. H., and D. M. Johnson. 1985. Behavior and ecological interactions of larval Odonata. Ecology 66:1504-1512.

Pimm, S. L. 1982. Food webs. Chapman \& Hall, New York.

Posada, D., and K. A. Crandall. 1998. MODELTEST: testing the model of DNA substitution. Bioinformatics 14:817-818.

Price, T., I. J. Lovette, E. Bermingham, H. L. Gibbs, and A. D. Richman. 2000. The imprint of history on communities of North American and Asian warblers. American Naturalist 156:354-367.

Rosenzweig, M. L. 1995. Species diversity in space and time. Cambridge University Press, New York.

Roughgarden, J. 1974. Species packing and the competition function with illustrations from coral reef fish. Theoretical Population Biology 9:388-424.

Sawchyn, E. E., and C. Gillott. 1974a. The life history of Lestes congener (Odonata: Zygoptera) on the Canadian prairies. Canadian Entomologist 106:367-376.

- 1974b. The life history of three species of Lestes (Odonata: Zygoptera) in Saskatchewan. Canadian Entomologist 106:12831293.

Schluter, D. 1986. Tests for similarity and convergence of finch communities. Ecology 67:1073-1085.

Schluter, D., and J. D. McPhail. 1993. Character displacement and replicate adaptive radiation. Trends in Ecology \& Evolution 8:197200.

Seehausen, O., J. J. M. van Alphen, and F. Witte. 1997. Cichlid fish diversity threatened by eutrophication that curbs sexual selection. Science 277:1808-1811.

Simon, C., F. Frati, A. Beckenbach, B. Crespi, H. Liu, and P. Flook. 1994. Evolution, weighting, and phylogenetic utility of mitochondrial gene-sequences and a compilation of conserved polymerase chain-reaction primers. Annals of the Entomological Society of America 87:651-701.

Sokal, R. R., and F. J. Rohlf. 1995. Biometry. 3rd ed. W. H. Freeman, New York.

Stoks, R., and F. Johansson. 2000. Trading off mortality risk against foraging effort in damselflies that differ in life cycle length. Oikos 91:559-567.

Stoks, R., and M. A. McPeek. 2003a. Antipredator behaviour and physiology determine Lestes species turnover along the pondpermanence gradient. Ecology 84:3327-3338.

- 2003b. Predators and life histories shape Lestes damselfly assemblages along a freshwater habitat gradient. Ecology 84:15761587.

Stoks, R., M. A. McPeek, and J. L. Mitchell. 2003. Evolution of prey behavior in response to changes in predation regime: damselflies in fish and dragonfly lakes. Evolution 57:574-585.

Stoks, R., M. De Block, and M. A. McPeek. 2005a. Alternative growth and energy storage responses to mortality threats in damselflies. Ecology Letters 8:1307-1316.

Stoks, R., J. L. Nystrom, M. L. May, and M. A. McPeek. 2005b. Parallel evolution in ecological and reproductive traits to produce cryptic damselfly species across the Holarctic. Evolution 59:1976-1988.

Stoks, R., M. De Block, F. Van de Meutter, and F. Johansson. 2005 c. Predation cost of rapid growth: behavioural coupling and physiological decoupling. Journal of Animal Ecology 74:705-715.

Stoks, R., M. De Block, S. Slos, W. Van Doorslaer, and J. Rolff. 2006. Time constraints mediate predator-induced plasticity in immune function, condition and life history. Ecology 87:809-815.

Swofford, D. L. 2001. PAUP*: phylogenetic analysis using parsimony, version $4.0 \mathrm{~b} 10$ for Windows. Sinauer, Sunderland, MA.

Thompson, J. N. 1999. Specific hypotheses on the geographic mosaic of coevolution. American Naturalist 153(suppl.):S1-S14.

. 2005. The geographic mosaic of coevolution. University of Chicago Press, Chicago.

Tilman, D. 2004. Niche tradeoffs, neutrality, and community structure: a stochastic theory of resource competition, invasion, and community assembly. Proceedings of the National Academy of Sciences of the USA 101:10854-10861.

Tokeshi, M. 1999. Species coexistence: ecological and evolutionary perspectives. Blackwell Science, Malden, MA. 
Tregonning, K., and A. Roberts. 1978. Complex systems which evolve towards homeostasis. Nature 281:563-564.

Turgeon, J., and M. A. McPeek. 2002. Phylogeographic analysis of a recent radiation of Enallagma damselflies (Odonata: Coenagrionidae). Molecular Ecology 11:1989-2001.

Turgeon, J., R. Stoks, R. A. Thum, J. M. Brown, and M. A. McPeek. 2005. Simultaneous quaternary radiations of three damselfly clades across the Holarctic. American Naturalist 165:E78-E107.

Webb, C. O., D. D. Ackerly, M. A. McPeek, and M. J. Donoghue. 2002. Phylogenies and community ecology. Annual Review of Ecology and Systematics 33:475-505.

Wellborn, G. A., D. K. Skelly, and E. E. Werner. 1996. Mechanisms creating community structure across a freshwater habitat gradient. Annual Review of Ecology and Systematics 27:337-363.

Weller, S. J., D. P. Pashley, J. A. Martin, and J. L. Constable. 1994. Phylogeny of noctuoid moths and the utility of combining independent nuclear and mitochondrial genes. Systematic Biology 43:194-211.
Werner, E. E., and M. A. McPeek. 1994. The roles of direct and indirect effects on the distributions of two frog species along an environmental gradient. Ecology 75:1368-1382.

Westfall, M. J., and M. L. May. 1996. Damselflies of North America. Scientific Publishers, Gainesville, FL.

Wiggins, G. B., Mackay, R. J., and I. M. Smith. 1980. Evolutionary and ecological strategies of animals in annual temporary pools. Archiv für Hydrobiologie 5 8:97-206.

Wiseman, S. W., S. D. Cooper, and T. L. Dudley. 1993. The effects of trout on epibenthic odonate naiads in stream pools. Freshwater Biology 30:133-145.

Wissinger, S. A., H. H. Whiteman, G. B. Sparks, G. L. Rouse, and W. S. Brown. 1999. Foraging trade-offs along a predatorpermanence gradient in subalpine wetlands. Ecology 80:21022116.

Associate Editor: Bradley R. Anholt 